\title{
Chemical Characterisation, Antioxidant and Antibacterial Activities of Pinus pinaster Ait. and Pinus pinea L. Bark Polar Extracts: Prospecting Forestry By-Products as Renewable Sources of Bioactive Compounds
}

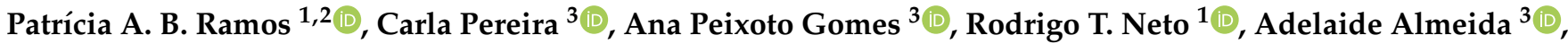 \\ Sónia A. O. Santos ${ }^{1, *(\mathbb{D})}$, Artur M. S. Silva ${ }^{2}$ and Armando J. D. Silvestre ${ }^{1}$ (D) \\ 1 CICECO—Aveiro Institute of Materials, Department of Chemistry, University of Aveiro, \\ 3810-193 Aveiro, Portugal; patriciaaramos@ua.pt (P.A.B.R.); rtneto@ua.pt (R.T.N.); armsil@ua.pt (A.J.D.S.) \\ 2 LAQV-REQUIMTE, Department of Chemistry, University of Aveiro, 3810-193 Aveiro, Portugal; \\ artur.silva@ua.pt \\ 3 CESAM - Centre for Environmental and Marine Studies, Department of Biology, University of Aveiro, \\ 3810-193 Aveiro, Portugal; csgp@ua.pt (C.P.); ana.peixoto@ua.pt (A.P.G.); aalmeida@ua.pt (A.A.) \\ * Correspondence: santos.sonia@ua.pt; Tel.: +351-234-370-711
}

Citation: Ramos, P.A.B.; Pereira, C. Gomes, A.P.; Neto, R.T.; Almeida, A.; Santos, S.A.O.; Silva, A.M.S.; Silvestre, A.J.D. Chemical Characterisation, Antioxidant and Antibacterial Activities of Pinus pinaster Ait. and Pinus pinea L. Bark Polar Extracts: Prospecting Forestry By-Products as Renewable Sources of Bioactive Compounds. Appl. Sci. 2022, 12, 784. https://doi.org/ 10.3390/app12020784

Academic Editors: Alessandra Durazzo and Samuel B. Adeloju

Received: 25 November 2021

Accepted: 9 January 2022

Published: 13 January 2022

Publisher's Note: MDPI stays neutral with regard to jurisdictional claims in published maps and institutional affiliations.

Copyright: (C) 2022 by the authors. Licensee MDPI, Basel, Switzerland. This article is an open access article distributed under the terms and conditions of the Creative Commons Attribution (CC BY) license (https:// creativecommons.org/licenses/by/ $4.0 /)$.

\begin{abstract}
Agroforestry by-products have gained rising attention in recent years as they represent inexpensive and abundant raw materials that are a source of added-value chemicals, e.g., for food and pharmaceutical applications, as well as for bioenergy generation. Pinus pinaster Ait. bark extracts are consumed worldwide for their cardiovascular benefits, whilst the health potential of Pinus pinea L. bark has not yet been deeply exploited. Therefore, this study highlights the chemical characterisation of Portuguese P. pinaster Ait. and P. pinea L. bark polar extracts, via ultra-high performance liquid chromatography-diode array detection-tandem mass spectrometry (UHPLC-DAD-MS ${ }^{n}$ ) analysis, and their antioxidant and antibacterial activities. Quinic acid, an A-type procyanidin dimer isomer, protocatechuic acid, and quercetin were identified for the first time as P. pinea L. bark components. Moreover, this bark demonstrated a higher total content of identified polar compounds than P. pinaster Ait. bark, with quinic acid being the most abundant compound identified. Regarding antioxidant activity, the pine bark polar extracts exhibited strong reducing power and 2,2-diphenyl-1-picrylhydrazyl (DPPH) and 2,2-azinobis-(3-ethyl-benzothiazoline-6-sulfonic acid (ABTS) radical scavenging effects compared to natural antioxidants. Moreover, the bactericidal actions of pine bark extracts were shown against Staphylococcus aureus and Escherichia coli at a $3.13-25 \mathrm{mg} \mathrm{mL}^{-1}$ range. Globally, these promising insights can boost the sustainable exploitation of $P$. pinea L. bark, as already occurs with P. pinaster Ait. bark, for the food and biomedical fields.
\end{abstract}

Keywords: Pinus pinaster Ait.; Pinus pinea L.; pine bark polar extracts; UHPLC-DAD-MS ${ }^{n}$ analysis; quinic acid; phenolic compounds; antioxidant activity; antibacterial activity; biorefinery

\section{Introduction}

In the scope of the 2030 Agenda for Sustainable Development, countries and stakeholders are committed to contributing to society and to world prosperity, tackling economic, social, and environmental challenges [1]. In particular, the management of forests affects not only human livelihood, health, and wellbeing but also food production and biodiversity preservation [2]. Therefore, Goal 15 of the 2030 Agenda is devoted to avoiding deforestation, restoring degraded forests, and promoting afforestation and reforestation [1]. Indeed, forests are scattered in ca. 31\% of the global land area, representing $4.06 \times 10^{9}$ ha in 2020 [2]. In Portugal, the agroforest activity is very important for the national economy and ecosystem balance, occupying $36 \%$ of the continental soil (ca. $3.2 \times 10^{6}$ ha), according to data from 2015 [3]. Pinus ssp. represents the second major tree family in Portuguese 
forests (ca. $9.6 \times 10^{5}$ ha of continental soil), after the Quercus spp. family. The Portuguese pine forest mainly consists of Pinus pinaster Ait. and P. pinea L., which, in 2015, accounted for ca. $7.1 \times 10^{5}$ and $1.9 \times 10^{5}$ ha of the continental soil, respectively [3]. Given their good adaptation to edaphoclimatic conditions, notably frost resistance, adaptation to summer drought, and tolerance to poor soils, P. pinaster Ait. has been planted for coastal sand dunes stabilisation, soil conservation, and agricultural culture protection against salt spray.

Additionally, P. pinaster Ait. wood plays a crucial role in the national economy as it is used for construction, furniture, panels, pulp fibers, and energy generation, whereas the resin is primarily intended for manufacturing oils, varnishes, and adhesives [4,5]. In a similar way, P. pinea L. is also well-adapted to the coastal Mediterranean climate and thrives preferentially in siliceous and sandy soils. Thus, P. pinea L. has been also cultivated in sand dunes for coastal area preservation. Furthermore, the edible seeds or nuts are considered to be the most economically valuable product of the $P$. pinea $\mathrm{L}$. forest due to their unique taste and also their interesting nutritional composition in terms of proteins, fats, ascorbic acid, thiamine, and riboflavin [6].

Both the pine wood and the seed industries generate considerable quantities of byproducts, mainly of the P. pinaster Ait. and P. pinea L. barks, accounting, in 2015, for 5000 and $600 \mathrm{t}$ in Portugal, respectively [3]. Pinus spp. bark has been used for energy generation, but it can be valorised as a renewable and low-cost source of biologically active compounds for food, nutraceutical, and pharmaceutical applications [7]. Actually, Pycnogenol ${ }^{\circledR}$, Flavangenol ${ }^{\circledR}$, and Oligopin ${ }^{\circledR}$ are commercially available extracts of P. pinaster Ait. bark, which contains phenolic compounds, namely procyanidins, phenolic acids (e.g., protocatechuic, gallic, ferulic, and caffeic acids), and flavanones (e.g., taxifolin and taxifolin-3'- $\beta$-D-glucoside) [7-9]. These commercial extracts have been associated with diverse health benefits. Pycnogenol ${ }^{\circledR}$ is generally used to treat circulation and cardiovascular disorders, whereas Flavangenol ${ }^{\circledR}$ has exhibited antihypertensive and arteriosclerosissuppressing potential [7]. Interestingly, P. pinaster Ait. bark phenolic-rich extracts have also demonstrated effective antioxidant and antimicrobial actions, whilst the biological potential of P. pinea L. bark polar fractions has not yet been deeply exploited [10-14]. Additionally, food and cosmetic stakeholders are more and more interested in sustainably exploiting natural antioxidant and antibacterial compounds, such as phenolic compounds, rather than using synthetic additives. Given these bioactivities, phenolic compounds have shown potential for the improvement of food shelf life and nutritional value, as well as for skin care and treatment $[15,16]$.

In this vein, Pinus spp. bark, which, as mentioned above, is available in large quantities, can be prospected as a promising source of bioactive compounds for food and nutraceutical applications, contributing to its sustainable valorisation within the bioeconomy concept. Nonetheless, the detailed chemical composition of $P$. pinea L. bark polar fractions and their related antioxidant and antibacterial activities are still poorly explored $[14,17,18]$ in comparison to P. pinaster Ait. bark $[10,13,19,20]$.

Considering our interest in the valorisation of agroforest by-products [21-23], the present work aims to deepen knowledge regarding the chemical composition, as well as the antioxidant and antibacterial activities, of P. pinaster Ait. and P. pinea L. bark polar extracts. Thus, the total phenolic content and proanthocyanidin (PAC) content were determined by using spectrophotometric assays, whilst the phenolic compounds were identified and quantified via ultra-high performance liquid chromatography-diode array detection-tandem mass spectrometry (UHPLC-DAD-MS ${ }^{n}$ ). The antioxidant activity was in chemico analysed by DPPH and ABTS scavenging effects as well as, for the first time, through reducing power assay. Moreover, the in vitro antibacterial effect was approached against the growth of Gram-positive Staphylococcus aureus and Gram-negative Escherichia coli pathogenic bacteria, which were selected considering that $S$. aureus is one of the leading causes of bacteremia and the second leading pathogen causing sepsis in industrialized countries, being responsible for skin, soft tissue, and bone infections and gastrointestinal problems [24], while E. coli is a major cause of diarrhea and is commonly associated with 
extraintestinal infections in humans and animals [25]. To the best of our knowledge, the antibacterial activity of the $P$. pinea L. bark polar extract against $E$. coli is reported here for the first time.

\section{Materials and Methods}

\subsection{Chemicals}

Dichloromethane (p.a., $\geq 99 \%$ ), methanol (p.a., $\geq 99.8 \%$ ), HPLC-grade methanol, and acetonitrile were supplied by Fisher Scientific (Pittsburgh, PA, USA). Before UHPLC analysis, mobile phase solvents were previously filtered through a Solvent Filtration Apparatus 58061 from Supelco (Bellefonte, PA, USA). Acetic acid glacial (p.a., $\geq 99.5 \%$ ) was purchased from Labkem (Madrid, Spain). Sodium carbonate (p.a., $\geq 99.9 \%$ ) was obtained from Panreac AppliChem ITW Reagents (Barcelona, Spain). Gallic acid ( $\geq 97.5 \%)$, Folin-Ciocalteu's phenol reagent $(2 \mathrm{~N})$, HPLC-grade water, formic acid $(\geq 98 \%)$, protocatechuic acid $(>97 \%)$, catechin hydrate $(>99 \%)$, quercetin $(>98 \%)$, taxifolin ( $\geq 85 \%)$, 2,2-diphenyl-1-picrylhydrazyl radical $\left(\mathrm{DPPH}^{\bullet}\right.$ ), 2,2-azinobis-(3-ethyl-benzothiazoline-6-sulfonic acid) (ABTS) diammonium salt, ascorbic acid ( $\geq 99.5 \%$ ), and ( \pm )-6-hydroxy-2,5,7,8-tetramethylchromane-2-carboxylic acid (hereinafter named as Trolox) (97\%) were supplied by Sigma-Aldrich (St. Louis, MO, USA). Sodium dihydrogen phosphate dihydrate was purchased from Panreac (pa., 99.0-101.0\%), and disodium hydrogen phosphate dihydrate (pa., 98\%) was supplied by Fluka. Potassium ferrocyanide (pa., $\geq 99.0 \%$ ) was obtained from Carlo Erba. Trichloroacetic acid (pa., 99\%) and iron (III) chloride (pa., 98\%) were purchased from Alfa Aesar.

\subsection{Pinus spp. Bark Samples}

The P. pinaster Ait. and P. pinea L. barks were sampled in January 2017 from the nearby Aveiro region, Portugal. After 2 weeks of air-drying, these pine bark samples were milled using a coffee milling machine, and then, a fraction with particle size lower than $1 \mathrm{~mm}$ was selected. The samples were kept at room temperature and in the dark before analysis.

\subsection{Preparation of Pinus spp. Bark Polar Extracts}

Lipophilic compounds were previously extracted from the milled bark of Pinus spp. bark, as mentioned elsewhere [22]. Thereafter, $2 \mathrm{~g}$ of dry bark residue was submitted to a methanol/water/acetic acid (49.5:49.5:1, $/ v / v)$ extraction for $24 \mathrm{~h}$, at constant stirring (900 r.p.m.), in the dark. After separation of the extract from the biomass via vacuum filtration, the methanol was evaporated at low pressure using a rotative evaporator, and water was removed by freeze-drying. Pinus spp. bark polar extracts were obtained in triplicate, and the respective extractive yields (EYs) were expressed as the percentage of dry bark. The extracts were left in the dark, at room temperature, until their analyses were carried out.

\subsection{Total Phenolic Content}

The total phenolic content (TPC) of the Pinus spp. barks was evaluated using the Folin-Ciocalteu reagent, following a previously described procedure $[23,26]$, with some adaptations [21]. The TPC was determined through a standard curve of gallic acid (5-100 $\left.\mu \mathrm{g} \mathrm{mL}^{-1}\right)$ and expressed as $\mathrm{mg}$ of gallic acid equivalents (GAE) per $\mathrm{g}$ of extract and $\mathrm{g}$ GAE per $\mathrm{kg}$ of dw. Two aliquots of each pine bark extract were tested in triplicate.

\subsection{Proanthocyanidins Content}

The proanthocyanidins content (PC) was determined through the acid butanol assay, according to the method described elsewhere [27]. Three bark polar extracts of each pine species were dissolved in methanol/water $(50: 50, v / v)$ at $1 \mathrm{mg} \mathrm{mL}^{-1}$. The absorbance of the cynanidin chromophore was recorded at $520 \mathrm{~nm}$ using the Thermo Scientific Multiskan ${ }^{\mathrm{TM}}$ FC microplate reader (Thermo Fisher Scientific Inc., Waltham, MA, USA). The PC was calculated via the linear regression equation of PACs purified from 
grape pomace (100-500 $\mu \mathrm{g} \mathrm{mL}^{-1}$ ) and expressed as mg of PAC per $\mathrm{g}$ of extract and $\mathrm{g}$ of PAC per kg of bark dw. Two aliquots of each pine bark extract were tested in triplicate.

\subsection{Qualitative Analysis of Polar Extracts by UHPLC-DAD-MS ${ }^{n}$ Analysis}

UHPLC-UV-MS ${ }^{n}$ analysis of the Pinus spp. bark extracts was carried out in a UHPLC system equipped with an Accela $600 \mathrm{LC}$ pump, an Accela autosampler (set at $16^{\circ} \mathrm{C}$ ), and an Accela $80 \mathrm{~Hz}$ photo diode array detector (DAD) (Thermo Fisher Scientific, San Jose, CA, USA). The extracts were prepared in methanol/water (50:50, v/v) at $10 \mathrm{mg} \mathrm{mL}^{-1}$ and the filtration process was carried out by tetrafluoroethylene filter having pore size $0.2 \mu \mathrm{m}$. The injection volume was $10 \mu \mathrm{L}$. The column used for separation was a Hypersil Gold RP C18 $(100 \times 2.1 \mathrm{~mm} ; 1.9 \mu \mathrm{m}$ packing) provided by Thermo Fisher Scientific (San Jose, CA, USA), with a C18 pre-column (2.1 mm i.d.) supplied by Thermo Fisher Scientific (San Jose, CA, USA); both were kept at $45^{\circ} \mathrm{C}$. The mobile phase composed of water:acetonitrile $(99: 1, v / v)(\mathrm{A})$ and acetonitrile (B), each containing $\mathrm{HCOOH}(0.1 \%(v / v))$. Gradient elution was carried out at a flow rate of $0.45 \mathrm{~mL} \mathrm{~min}{ }^{-1}$ for $32 \mathrm{~min}$, as follows: $1 \% \mathrm{~B}$ kept from 0 to $3 \mathrm{~min} ; 1-31 \%$ B over $27 \mathrm{~min}$; and 31-100\% B over $2 \mathrm{~min}$, followed by reequilibration at $1 \% \mathrm{~B}$ for $4 \mathrm{~min}$. The chromatograms were recorded at 280 and $370 \mathrm{~nm}$, and UV spectra collected from 210 to $600 \mathrm{~nm}$.

The UHPLC system was coupled to an LCQ Fleet ion trap mass spectrometer (ThermoFinnigan, San Jose, CA, USA) with an electrospray ionization (ESI) source, conducted in the negative ionization mode, according to previously described conditions [21].

\subsection{Quantitative Analysis of Polar Extracts by UHPLC-UV Analysis}

Standard solutions of gallic and protocatechuic acids, catechin, naringenin, and quercetin were injected in the UHPLC to obtain standard curves. The solutions were prepared in HPLC grade methanol, with six concentrations ranging from 0.45 to $41.04 \mu \mathrm{g} \mathrm{mL}^{-1}$. The compounds were quantified by using the linear regression equation (Table 1) of the most similar standard compound. The pine bark extracts were injected in triplicate.

Table 1. UHPLC-UV standard data used for the quantitative analysis of the identified compounds in Pinus spp. bark polar extracts.

\begin{tabular}{|c|c|c|c|c|c|c|}
\hline Standard & $\lambda(\mathrm{nm})^{1}$ & $\begin{array}{c}\text { Concentration } \\
\text { Range }\left(\mu \mathrm{g} \mathrm{mL}^{-1}\right)\end{array}$ & $\begin{array}{c}\text { Linear Regression } \\
\text { Equation }^{2}\end{array}$ & $R^{2}$ & $\begin{array}{c}\mathrm{LOD}^{3} \\
\left(\mu \mathrm{g} \mathrm{mL}^{-1}\right)\end{array}$ & $\begin{array}{c}\mathrm{LOQ}^{4} \\
\left(\mu \mathrm{g} \mathrm{mL}^{-1}\right)\end{array}$ \\
\hline Catechin & 280 & $0.50-30.29$ & $y=30528 x-19621$ & 0.9973 & 2.08 & 6.93 \\
\hline Gallic acid & 280 & $0.52-31.20$ & $y=104717 x-38562$ & 0.9986 & 1.56 & 5.19 \\
\hline Naringenin & 280 & $0.51-41.04$ & $y=394428 x+172880$ & 0.9999 & 0.44 & 1.48 \\
\hline Protocatechuic acid & 280 & $0.50-30.26$ & $y=112312 x-18937$ & 0.9997 & 0.66 & 2.20 \\
\hline Quercetin & 370 & $0.45-27.05$ & $y=364286 x-66014$ & 0.9949 & 2.55 & 8.51 \\
\hline
\end{tabular}

${ }^{1}$ Wavelength used in the HPLC-UV quantification. ${ }^{2} y$ and $x$ represent peak area and concentration in $\mu \mathrm{g} \mathrm{mL}{ }^{-1}$, respectively. ${ }^{3} \mathrm{LOD}$, limit of detection. ${ }^{4} \mathrm{LOQ}$, limit of quantification.

\subsection{Antioxidant Activity}

\subsubsection{Reducing Power}

The reducing power was assayed according to the procedure described [28], with some modifications, and adapted to the 96 -well microplate scale. Trolox was considered as the antioxidant reference. The stock solution of Trolox was prepared in methanol, whilst three bark polar extracts of each Pinus spp. were dissolved in methanol/water (50:50, $v / v)$ at $1 \mathrm{mg} \mathrm{mL}^{-1}$. Different volumes of extract and standard stock solutions were added to deionised water up to $1000 \mu \mathrm{L}$ and then mixed with $1000 \mu \mathrm{L}$ of $0.2 \mathrm{M}$ phosphate buffer solution ( $\mathrm{pH}$ 6.6) and $1000 \mu \mathrm{L}$ of $1 \%(w / v)$ potassium ferrocyanide solution, obtaining the concentration ranges of 3.4-49.5 $\mu \mathrm{g} \mathrm{mL}^{-1}$ and 3.6-71.1 $\mu \mathrm{g} \mathrm{mL}^{-1}$ for the extracts and Trolox, respectively. The reactional mixture was kept at $50{ }^{\circ} \mathrm{C}$ for $20 \mathrm{~min}$. Thereafter, $1000 \mu \mathrm{L}$ of $10 \%(w / v)$ trichloroacetic acid solution was added to stop the redox reaction, and the mixture was left to cool to room temperature for $10 \mathrm{~min}$. An aliquot of $125 \mu \mathrm{L}$ of 
the mixture was transferred to the microplate well, and $125 \mu \mathrm{L}$ of deionised water and $25 \mu \mathrm{L}$ of $0.1 \%(w / v)$ ferric (III) chloride solution were added. Then, the absorbance was recorded against the blank at $690 \mathrm{~nm}$ in a Thermo Scientific Multiskan ${ }^{\mathrm{TM}}$ FC microplate reader. An increased absorbance means a higher reducing power of sample. The halfmaximal inhibitory concentration $\left(\mathrm{IC}_{50}\right)$ was considered as the sample concentration at which the absorbance was measured as 0.500 , being calculated through the respective linear regression equations from the graph plotting absorbance at $690 \mathrm{~nm}$ against the sample concentration. Each concentration was tested in triplicate.

The reducing power represents a ferric-ion-based total antioxidant capacity assay, in which the potassium ferricyanide $\left(\mathrm{K}_{3}\left[\mathrm{Fe}(\mathrm{CN})_{6}\right]\right)$ is the oxidant species and reacts with the antioxidant, forming potassium ferrocyanide $\left(\mathrm{K}_{4}\left[\mathrm{Fe}(\mathrm{CN})_{6}\right]\right)$ and the oxidized antioxidant (Equation (1)). Then, potassium ferrocyanide combines with ferric chloride $\left(\mathrm{FeCl}_{3}\right)$, yielding the Prussian blue chromophore $\left(\mathrm{KFe}\left[\mathrm{Fe}(\mathrm{CN})_{6}\right]\right)$ (Equation (2)). The reducing power of the tested extract or compound increases as much as the absorbance of Prussian blue [29].

$$
\begin{gathered}
\mathrm{K}_{3}\left[\mathrm{Fe}(\mathrm{CN})_{6}\right]+\text { antioxidant } \rightleftarrows \mathrm{K}_{4}\left[\mathrm{Fe}(\mathrm{CN})_{6}\right]+\text { oxidized antioxidant } \\
\mathrm{K}_{4}\left[\mathrm{Fe}(\mathrm{CN})_{6}\right]+\mathrm{FeCl}_{3} \rightleftarrows \mathrm{KFe}\left[\mathrm{Fe}(\mathrm{CN})_{6}\right]
\end{gathered}
$$

\subsubsection{DPPH Free Radical Scavenging Effect}

The antioxidant activity against DPPH of Pinus spp. bark extracts was approached as explained before [21,30] and adapted to the 96-well plate scale. Ascorbic acid was used as the antioxidant reference, being dissolved in methanol/water (50:50, v/v) at $1 \mathrm{mg}$ $\mathrm{mL}^{-1}$. Stock solutions $\left(1 \mathrm{mg} \mathrm{mL}^{-1}\right)$ of three polar extracts from the $P$. pinaster Ait. and $P$. pinea L. barks were also prepared in methanol/water (50:50, v/v). Briefly, in each well, $30 \mu \mathrm{L}$ of $1 \mathrm{mM}$ DPPH methanolic solution was mixed to $75 \mu \mathrm{L}$ of sample and $195 \mu \mathrm{L}$ of methanol, obtaining the concentration ranges of $1.0-43.2 \mu \mathrm{g} \mathrm{mL} \mathrm{m}^{-1}$ for the extracts and $0.5-15.9 \mu \mathrm{g} \mathrm{mL}^{-1}$ for ascorbic acid. The blank was composed of $30 \mu \mathrm{L}$ of DPPH $(1 \mathrm{mM})$ in methanol and $270 \mu \mathrm{L}$ of methanol. After mixing, the microplate was protected from the light for $30 \mathrm{~min}$. The absorbance of the resulting solution was measured at $520 \mathrm{~nm}$ in a microplate reader (Thermo Scientific Multiskan ${ }^{\mathrm{TM}}$ FC). The DPPH scavenging effect percentage was determined according to Equation (3).

$$
\text { DPPH scavenging effect }(\%)=\left[\frac{A_{\text {control }}-A_{\text {sample }}}{A_{\text {control }}}\right] \times 100 \%
$$

The $\mathrm{IC}_{50}$ was determined by plotting the percentage of scavenged DPPH free radicals against the concentration logarithm. For comparison reasons, the AAI was calculated according to Equation (4) [31].

$$
A A I=\frac{D P P H_{\text {final concentration }}\left(\mu g m L^{-1}\right)}{I C_{50}\left(\mu g m L^{-1}\right)}
$$

with the DPPH final concentration equal to $61.874 \mu \mathrm{g} \mathrm{mL} \mathrm{m}^{-1}$. Each concentration was assayed in triplicate.

\subsubsection{ABTS Radical Cation Scavenging Effect}

The ABTS radical cation $\left(\mathrm{ABTS}^{\bullet+}\right.$ ) scavenging activity of the Pinus spp. bark extracts was measured according to a described procedure [23,32] and adapted to the 96-well plate scale. Firstly, stock solutions $\left(1 \mathrm{mg} \mathrm{mL}^{-1}\right)$ of three bark polar extracts from each Pinus species were prepared in methanol/water (50:50,v/v). Moreover, stock solutions $\left(1 \mathrm{mg} \mathrm{mL}^{-1}\right)$ of ascorbic acid and trolox (antioxidant standards) were prepared in methanol/water (50:50, v/v) and methanol, respectively. The ABTS radical cation was prepared by reacting $7 \mathrm{mM}$ ABTS with $2.45 \mathrm{mM}$ potassium persulfate. The reactional mixture was kept in the dark at room temperature for $16 \mathrm{~h}$ and then diluted with methanol, to give 
an absorbance value of 0.700 at $750 \mathrm{~nm}$. In each microwell, $250 \mu \mathrm{L}$ of $\mathrm{ABTS}^{\bullet+}$ solution was mixed with $50 \mu \mathrm{L}$ of sample, obtaining the $0.5-21.2,0.5-15.9$, and $0.5-19.4 \mu \mathrm{g} \mathrm{mL}^{-1}$ concentration ranges for the extracts, ascorbic acid, and trolox, respectively. The control was constituted by $250 \mu \mathrm{L}$ of $\mathrm{ABTS}^{\bullet+}$ solution and $50 \mu \mathrm{L}$ of methanol. After $30 \mathrm{~min}$, protected from the light, the absorbance was recorded at $750 \mathrm{~nm}$ by a Thermo Scientific MultiskanTM FC microplate reader.

The $\mathrm{IC}_{50}$ was calculated by plotting the percentage of scavenged ABTS radical cation as a function of the sample concentration logarithm. Each concentration was tested in triplicate.

\subsection{Antibacterial Activity}

The antibacterial effect of the Pinus spp. bark polar extracts was tested against the growth of S. aureus (ATCC ${ }^{\circledR}$ 6538) and E. coli (ATCC ${ }^{\circledR} 25922$ ).

Before the antibacterial tests, a bacterial colony was inoculated in $30 \mathrm{~mL}$ of tryptic soy broth at $37^{\circ} \mathrm{C}$ and 170 r.p.m. for 18 h. Later, the bacterial culture was diluted in phosphate buffered saline (PBS) solution ( $\mathrm{pH} 7.4$ ), to be adjusted to $0.5 \mathrm{McF}$ arland standard, which corresponds to $10^{8}-10^{9}$ colony forming units (CFUs) per $\mathrm{mL}$. The bacterial inoculum was added to the Pinus spp. bark polar extracts, obtaining the final concentrations of $0.39,0.78$, $1.56,3.13,6.25$, and 12.5 e $25 \mathrm{mg} \mathrm{mL}^{-1}$. Two bacterial controls were included, namely a bacterial growth control with only bacterial inoculum and a solvent control containing bacterial inoculum with $12.5 \%(v / v)$ ethanol, representing the maximum amount of ethanol added to the bacterial culture. The bacterial suspensions were incubated at $37{ }^{\circ} \mathrm{C}$ and 120 r.p.m. for $24 \mathrm{~h}$. At $24 \mathrm{~h}$ of incubation, the aliquots of bacterial suspensions were sampled, serially diluted in PBS and plated in triplicate in tryptic soy agar. After the incubation at $37^{\circ} \mathrm{C}$ for $18 \mathrm{~h}$, the CFUs were calculated, and the viable bacterial density was determined as $\log$ CFU $\mathrm{mL}^{-1}$ and compared with the solvent control. The bacteriostatic

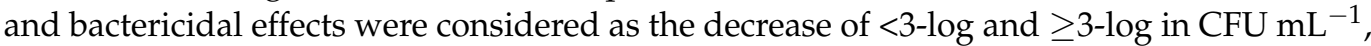
respectively. The assays were performed as three independent experiments, with three replicates for each concentration.

\subsection{Statistical Analysis}

The statistical analysis was performed using the IBM ${ }^{\circledR}$ SPSS $^{\circledR}$ Statistics Version 25 (IBM Corporation, New York, NY, USA). Tukey's Honestly Significant Difference (HSD) and Duncan Post Hoc Tests were used to determine the significance of difference $(p<0.05)$ for antioxidant and antibacterial activity data, respectively.

\section{Results and Discussion}

\subsection{Extraction Yield, Total Phenolic, and Proanthocyanidins Contents}

The polar extracts of the P. pinaster Ait. and P. pinea L. barks were obtained by solid liquid extraction with a mixture of methanol/water/acetic acid (49.5:49.5:1, $v / v / v)$, which has been shown to be suitable for the efficient extraction of phenolic compounds from biomass, e.g., cultivated cardoon and willow bark $[21,33]$. The obtained extraction yields (EYs) were $18.3 \pm 1.1 \%$ and $21.3 \pm 0.7 \% w / w$ dry weight $(\mathrm{dw})$ for the $P$. pinea L. and $P$. pinaster Ait. barks, respectively. These values were higher than those previously reported using ethanol (4.6-13.2\% $w / w$ dry P. pinaster Ait. bark and $12.1 \% w / w$ dry P. pinea L. bark) and water (2.4-3.2\% $w / w$ dry P. pinaster Ait. bark and 4.9\% w/w dry P. pinea L. bark) [10,34-36]. In addition to the extraction media, the geographical origin, edaphoclimatic conditions, pine tree age and cultivar, and sample conservation and extraction techniques can strongly affect EYs.

The P. pinaster Ait. and P. pinea L. bark polar extracts were evaluated regarding their TPC and PC, which are summarized in Table 2. The TPC of the studied Pinus spp. barks accounted for $103 \mathrm{~g}$ of gallic acid equivalents (GAE) $\mathrm{kg}^{-1} \mathrm{dw}$ in the P. pinea L. bark and $116 \mathrm{~g}$ of $\mathrm{GAE} \mathrm{kg}{ }^{-1} \mathrm{dw}$ in the $P$. pinaster Ait. bark. The TPC values reported here for the $P$. pinaster Ait. and the $P$. pinea L. bark extracts are within the described range for 
the aqueous and hydroethanolic extracts of $P$. pinaster Ait. bark collected in the north of Portugal (5.30-163.64 g GAE kg ${ }^{-1}$ bark) [10,37]. When the TPC was expressed as $\mathrm{mg}$ GAE per $\mathrm{g}$ of extract (Table 2), it ranged between $539 \mathrm{mg} \mathrm{g}^{-1}$ and $568 \mathrm{mg} \mathrm{g}^{-1}$ of the extracts derived from the P. pinaster Ait. and P. pinea L. barks, respectively. These values were in agreement with those described in the literature, regarding the ethanol, water, and alkaline extracts of $P$. pinaster Ait. bark (260-738.0 mg GAE g $^{-1}$ of extract) [38-40], including Pycnogenol ${ }^{\circledR}$ (572.28 mg GAE g ${ }^{-1}$ of extract) [41]. Furthermore, the TPCs of the studied extracts were concordant with those reported for the hot water extracts (HWE), derived from other Pinus spp. barks, ranging from a $111 \mathrm{mg} \mathrm{g}^{-1}$ extract of $P$. rigida $\mathrm{x}$ taeda to an $862 \mathrm{mg} \mathrm{g}^{-1}$ extract of P. koraiensis [42], as well as for the $80 \%(v / v)$ methanol extract of P. brutia bark (412.42 $\mathrm{mg} \mathrm{GAE} \mathrm{g}^{-1}$ extract) [43].

Table 2. Total phenolic content (TPC) and proanthocyanidin content (PC) of Pinus pinaster Ait. and Pinus pinea L. bark polar extracts.

\begin{tabular}{|c|c|c|c|c|}
\hline Pinus spp. by-Product & TPC (g GAE kg-1 dw) & $\begin{array}{c}\text { TPC (mg GAE g } g^{-1} \\
\text { of Extract) }\end{array}$ & PC (g PAC kg $\left.{ }^{-1} \mathrm{dw}\right)$ & $\begin{array}{c}\text { PC (mg PAC } \mathrm{g}^{-1} \\
\text { of Extract) }\end{array}$ \\
\hline P. pinaster Ait. bark & $116 \pm 11$ & $539 \pm 26$ & $174 \pm 12$ & $814 \pm 58$ \\
\hline P. pinea L. bark & $103 \pm 9$ & $568 \pm 12$ & $157 \pm 18$ & $857 \pm 50$ \\
\hline
\end{tabular}

The values represent the mean \pm standard deviation of two aliquots of each extract tested in triplicate. Abbreviations: GAE, gallic acid equivalents; PAC, proanthocyanidins purified from grape pomace; PC, proanthocyanidin content; TPC, total phenolic content.

Both Pinus spp. barks showed considerably high PCs (Table 2), accounting for 174 and $157 \mathrm{~g}$ PACs kg ${ }^{-1} \mathrm{dw}$ in the P. pinaster Ait. and P. pinea L. barks, respectively. Interestingly, the PC of the studied pine bark extracts was much higher than those of the alkaline extracts from the P. pinaster Ait. bark (1.20-5.43 g cyanidin equivalents $\mathrm{kg}^{-1}$ bark) [44], despite the use of a different standard. Actually, the PC determined through the cyanidin standard curve has been considered as underestimated as not all the PCs are converted into anthocyanidins [45]. When the PCs of the Pinus spp. bark polar extracts were expressed as $\mathrm{mg} \mathrm{PAC} \mathrm{g}^{-1}$ of the extract (Table 2), it varied between $814 \mathrm{mg} \mathrm{PAC}^{-1}$ of the P. pinaster Ait. bark extract and $857 \mathrm{mg} \mathrm{g}^{-1}$ of the P. pinea L. bark extract. These values are $\sim 22 \%$ higher than the value reported for Pycnogenol ${ }^{\circledR}$ (700 $\mathrm{mg} \mathrm{g}^{-1}$ extract) [8] and up to 6.7-fold higher than the values achieved for phloem extracts from P. pinaster and P. pinea [46].

\subsection{Chemical Characterisation of Pinus spp. Bark Polar Extracts}

\subsubsection{Qualitative Analysis}

The compounds present in the P. pinaster Ait. and P. pinea L. bark polar extracts were identified by UHPLC-DAD-MS ${ }^{n}$.

Table 3 lists the retention time, maxima UV wavelengths, the $[\mathrm{M}-\mathrm{H}]^{-}$ions, and the $\mathrm{MS}^{n}$ product ions of the 15 compounds (Figure 1) identified in the studied polar extracts. In addition to quinic acid (1), 14 phenolic compounds were found in the studied Pinus spp. barks, such as protocatechuic acid (2), 10 flavan-3-ols (3-12), 2 flavanonols (13-14), and a flavonol, i.e., quercetin (15). The identification of these compounds was performed by comparing the obtained spectroscopic results with the literature data and with those of the available commercial standards injected under the same experimental conditions, as discussed below. 
Table 3. UHPLC-DAD-MS ${ }^{n}$ data of compounds identified in Pinus pinaster Ait. and Pinus pinea L. bark polar extracts.

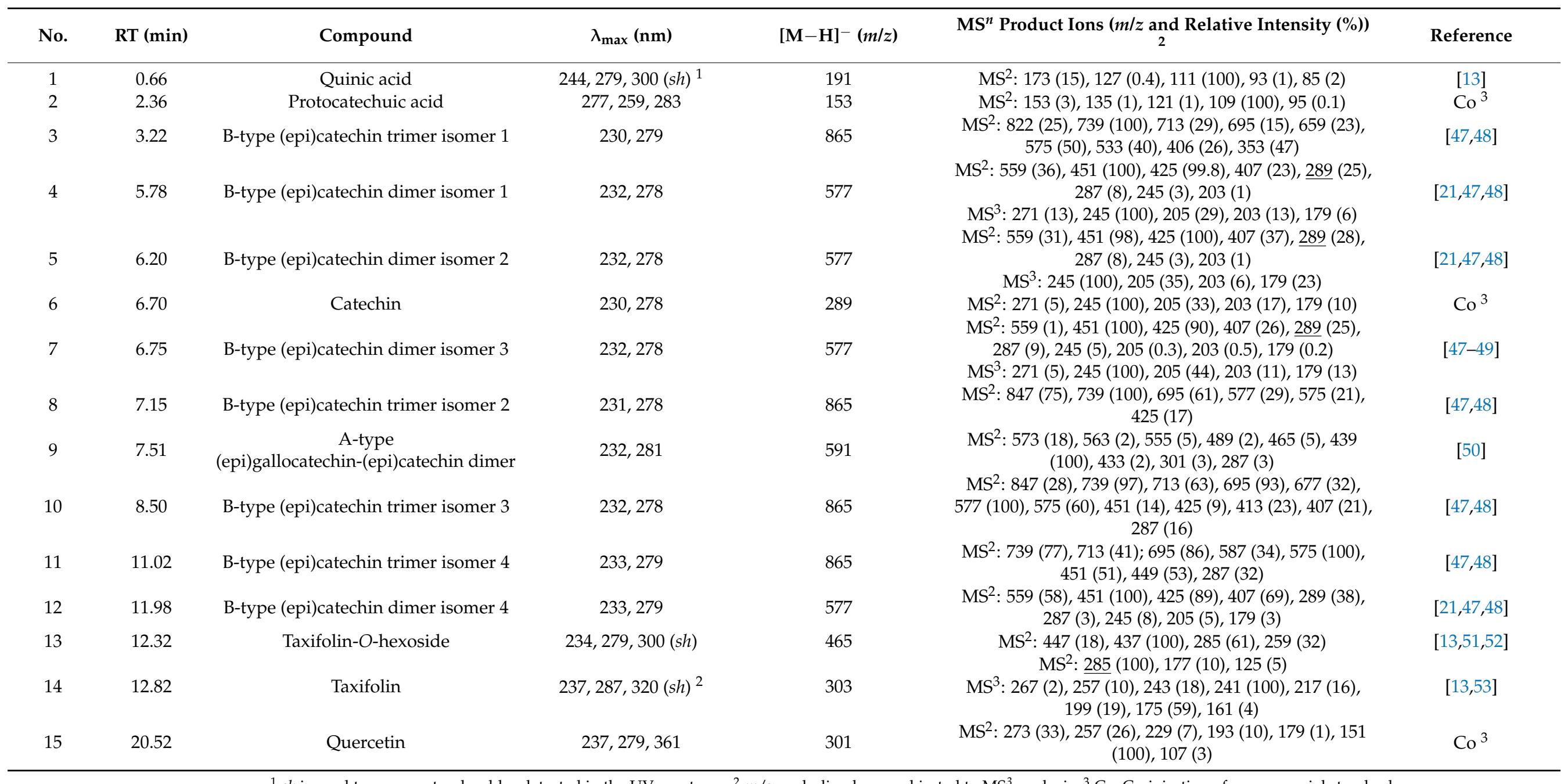

${ }^{1} \mathrm{sh}$ is used to represent a shoulder detected in the UV spectrum. ${ }^{2} \mathrm{~m} / \mathrm{z}$ underlined was subjected to $\mathrm{MS}^{3}$ analysis. ${ }^{3} \mathrm{Co}$, Co-injection of a commercial standard. 
<smiles>O=C(O)C1(O)CC(O)C(O)C(O)C1</smiles>

1 Quinic acid<smiles>Oc1cc(O)c2c(c1)OC(c1ccc(O)c(O)c1)C(O)C2c1c(O)cc(O)c2c1OC(c1ccc(O)c(O)c1)C(O)C2c1c(O)cc(O)c2c1OC(c1ccc(O)c(O)c1)C(O)C2</smiles>

2 Protocatechuic acid

3, 8, 10, 11 B-type procyanidin trimer isomers B<smiles>[R]Oc1cc(O)c2c(c1)OC(c1ccc(O)c(O)c1)C(O)C2=O</smiles><smiles>Oc1cc(O)c2c(c1)OC(c1ccc(O)c(O)c1)C(O)C2c1c(O)cc(O)c2c1OC(c1ccc(O)c(O)c1)C(O)C2</smiles>

4, 5, 7, 12 B-type procyanidin dimer isomers<smiles>Oc1cc(O)c2c(c1)O[C@H](c1ccc(O)c(O)c1)[C@H](O)C2</smiles><smiles>O=c1c(O)c(-c2ccc(O)c(O)c2)oc2cc(O)cc(O)c12</smiles>

Figure 1. Chemical structures of the compounds identified in Pinus pinaster Ait. and Pinus pinea L. bark polar extracts.

\section{- Flavan-3-ols}

Based on the characteristic UV absorption spectra, the corresponding $[\mathrm{M}-\mathrm{H}]^{-}$ions and respective $\mathrm{MS}^{n}$ fragmentations (Table 3), catechin (6), 4 B-type (epi)catechin dimers (4, 5, 7, and 12), 4 B-type (epi)catechin trimers (3, 8, 10, and 11), and an A-type (epi)gallocatechin(epi)catechin dimer (9) were identified in the analysed P. pinaster Ait. and P. pinea L. barks, as thoroughly described below.

Catechin (6) (Figure 2) was identified via the UV spectral data and the detection of the $[\mathrm{M}-\mathrm{H}]^{-}$ion at $m / z 289$, as well as its $\mathrm{MS}^{2}$ fragmentation $[21,54]$, which agreed with those obtained for a commercial standard injected under the same experimental conditions. (+)-Catechin has been previously identified in the hydroethanolic extracts of $P$. pinaster Ait. bark [10,37], as well as in the commercial pine bark extracts $[13,55,56]$. This compound has also been detected in the ethyl acetate fraction of the aqueous extract of the P. pinea L. bark from Turkey [17].

Four B-type (epi)catechin dimers (4, 5, 7, and 12) (Figure 1) were identified according to the UV absorption data and the $[\mathrm{M}-\mathrm{H}]^{-}$ion detected at $m / z 577$, as well as the characteristic product ions resulting from the $\mathrm{MS}^{2}$ fragmentation of the ion at $m / z 577[21,47,48]$. Furthermore, the (epi)catechin units present in compounds 4, 5, 7, and 12 can be bonded by $\mathrm{C} 4 \rightarrow \mathrm{C} 6$ or $\mathrm{C} 4 \rightarrow \mathrm{C} 8$ (B-type), but the obtained mass spectrometry data did not allow us to unequivocally distinguish between them (Figure 2 ) $[48,56]$. Considering that the procyanidin dimers identified so far in nature range from B1 to B16 [48], the identity of compounds 4, 5, 7, and 12 may be attributed to four of those procyanidins, with the exception of either procyanidins B10, B12, B13, and B16, as these include an epigallocatechin monomer, or procyanidin B11, due to the presence of a galloylcatechin upper subunit. Moreover, 
procyanidins B1, B3, B6, and B7 have been already identified in Pycnogenol ${ }^{\circledR}[8]$ and three B-type procyanidin isomers in P. pinea L. bark [17].

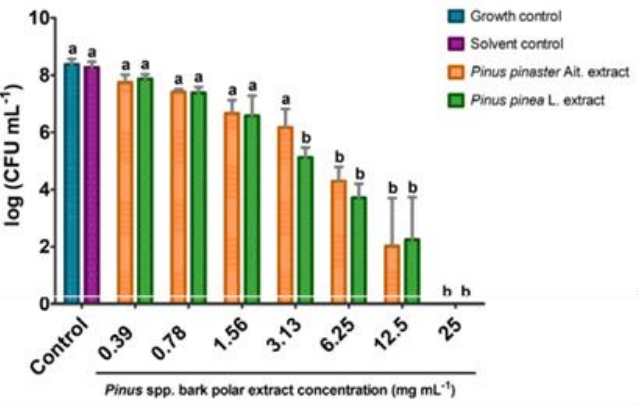

(A)

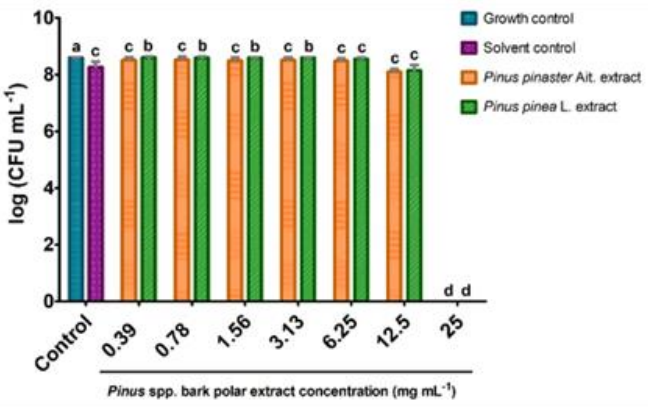

(B)

Figure 2. Inhibitory effect of Pinus pinaster Ait. and Pinus pinea L. bark polar extracts against the growth of (A) S. aureus (ATCC ${ }^{\circledR}$ 6538) and (B) E. coli (ATCC ${ }^{\circledR}$ 25922). The solvent control represents the bacterial growth under $12.5 \%(v / v)$ ethanol. The columns and bars depict, respectively, the mean and the mean-standard of the error of three independent experiments performed in triplicate. Columns with different letters are statistically different from the solvent control (unidirectional ANOVA followed by Duncan's Test; $p<0.05)$. CFU, colony forming units.

Compounds $3, \mathbf{8}, \mathbf{1 0}$, and $\mathbf{1 1}$ were tentatively identified as B-type (epi)catechin trimers as their molecular absorption spectra, the detection of the $[\mathrm{M}-\mathrm{H}]^{-}$ion at $m / z 865$, and the $\mathrm{MS}^{2}$ fragmentation of the $[\mathrm{M}-\mathrm{H}]^{-}$ion (Table 3) were in agreement with the literature data [48,57]. Indeed, the $\mathrm{MS}^{2}$ spectrum of the $[\mathrm{M}-\mathrm{H}]^{-}$ion at $m / z 865$ yielded the product ions at $m / z 577\left([\mathrm{M}-\mathrm{H}-288]^{-}\right)$and $m / z 287\left(\left[(\text { epi)catechin }-3 \mathrm{H}]^{-}\right)\right.$, resulting from the quinone-methide fission between the $\mathrm{C}$ and $\mathrm{D}$ rings, with the loss of the extension unit $[48,57]$. Furthermore, the retro Diels-Alder fission in the $\mathrm{C}$ ring of the $[\mathrm{M}-\mathrm{H}]^{-}$ ion at $m / z 865$ originated the product ion at $m / z 713$, which yielded the product ion at $m / z$ 695, after the loss of a water molecule [48]. Additionally, the product ions at $m / z$ $847\left(\left[\mathrm{M}-\mathrm{H}-\mathrm{H}_{2} \mathrm{O}\right]^{-}\right)$and $m / z 739$ (heterocyclic $\mathrm{C}$ ring fission) were detected. The product ion at $m / z 587$ yielded from the product ion at $m / z 739$ after the retro Diels-Alder fission in the F ring. In the $\mathrm{MS}^{2}$ [865] spectrum, the characteristic product ions at $m / z 451$ (heterocyclic F ring fission), $m / z 425$ (retro Diels-Alder fission in F ring), $m / z 407$ (loss of a water molecule from the product ion at $m / z 425$ ), and $m / z 287$ (trimer upper subunit after the quinone-methide fission between the $C$ and $D$ rings) were also found [47,48]. Interestingly, only one B-type procyanidin trimer isomer has already been found in commercial P. pinaster Ait. bark extracts [56,58], and two others in P. pinea L. bark [17].

Compound 9 was tentatively identified as an A-type procyanidin dimer (Figure 2) as its UV molecular absorption spectrum, the detection of the $[\mathrm{M}-\mathrm{H}]^{-}$ion at $m / z 591$, and the corresponding $\mathrm{MS}^{2}$ spectrum (Table 3) were all concordant with the literature data $[50,57,59]$. The chemical structure of this compound can be envisaged as one of four hypotheses, as follows: (epi)gallocatechin-( $2 \rightarrow \mathrm{O} 7,4 \rightarrow 8)$-(epi)catechin; (epi)gallocatechin-( $2 \rightarrow \mathrm{O} 5,4 \rightarrow 6)$ (epi)catechin; (epi)catechin-( $\rightarrow \mathrm{O} 7,4 \rightarrow 8)$-(epi)gallocatechin; or (epi)catechin-( $2 \rightarrow \mathrm{O} 5,4 \rightarrow 6)$ (epi)gallocatechin [50,59]. Considering the detection of the product ions at $m / z 301$ and $m / z 289$ in the $\mathrm{MS}^{2}$ spectrum of the ion at $m / z 591$, the former two hypotheses are more likely than the remaining two as these product ions represent, respectively, [(epi)gallocatechin $-5 \mathrm{H}]^{-}$and $\left[(\text {epi)catechin }-\mathrm{H}]^{-}\right.$ions formed by the methide fission between the $\mathrm{C}$ ring of the (epi)gallocatechin unit (upper unit) and the $\mathrm{D}$ ring of the (epi)catechin (terminal unit) [59] (Figure S1). Furthermore, the $\mathrm{MS}^{2}$ spectrum of the ion at $m / z 591$ presented a base peak at $m / z 439$, which resulted from the retro-Diels-Alder fission in the F-ring of the (epi)catechin unit, with the loss of 152 mass units (Figure S1), strengthening the hypothesis of (epi)catechin being the terminal unit of compound 9 [59]. Nonetheless, it is not possible to distinguish the linkages of the units solely by mass spectrometry [59]. Thus, the chemical structure of compound 9 may be an isomer of the 
(epi)gallocatechin-(epi)catechin dimer. To the best of our knowledge, this procyanidin isomer is identified here for the first time in the P. pinaster Ait. and P. pinea L. barks.

- Flavanonols

Compound 13 was assigned as taxifolin-O-hexoside (Figure 2), based on the UV molecular absorption spectrum, the $[\mathrm{M}-\mathrm{H}]^{-}$ion at $m / z 465$, and the corresponding $\mathrm{MS}^{2}$ spectrum [13,49]. Actually, this $\mathrm{MS}^{2}$ spectrum presented the product ion at $m / z 285$ due to the loss of a water molecule from the product ion at $m / z 303$ ([taxifolin-H] $]^{-}$) [13,51,52]. Additionally, taxifolin-O-hexoside was eluted before taxifolin (14), as reported elsewhere [13].

Compound 14 was identified as taxifolin (Figure 2) as its retention time, the UV spectrum, the detection of the $[\mathrm{M}-\mathrm{H}]^{-}$ion at $m / z 303$, and the respective $\mathrm{MS}^{2}$ and $\mathrm{MS}^{3}$ $[303 \rightarrow 285]$ data matched with those of the commercial standard injected under the same experimental conditions. Regarding the fragmentation data profile of this compound, the $\mathrm{MS}^{2}$ spectrum of the $[\mathrm{M}-\mathrm{H}]^{-}$ion at $m / z 303$ depicted the base peak at $m / z 285\left(\left[\mathrm{M}-\mathrm{H}-\mathrm{H}_{2} \mathrm{O}\right]^{-}\right)$, whilst the $\mathrm{MS}^{3}$ [303 $\rightarrow$ 285] fragmentation yielded the product ions at $\mathrm{m} / \mathrm{z} 243$ (loss of $\mathrm{C}_{2} \mathrm{H}_{2} \mathrm{O}$ ) and $m / z 217$ (loss of $\mathrm{C}_{3} \mathrm{O}_{2}$ ), due to the presence of $4^{\prime}$-hydroxyl groups at $\mathrm{C}^{\prime}$ in the $\mathrm{B}$ ring and at $\mathrm{C} 5$ or $\mathrm{C} 7$ in the $\mathrm{A}$ ring, respectively [60]. Indeed, taxifolin has also been identified in commercial $[13,55]$ and hydroethanolic $[10,37]$ extracts of P. pinaster Ait. bark. Two taxifolin isomers have also been described in P. pinea L. bark [17].

- Other compounds

The identification of quinic acid (1) (Figure 2) was based on the characteristic UV molecular absorption spectrum, the detection of the $[\mathrm{M}-\mathrm{H}]^{-}$at $m / z 191$, and the corresponding $\mathrm{MS}^{2}$ spectrum, which showed a base peak at $m / z 111$ and the characteristic product ions at $m / z 173\left(\left[\mathrm{M}-\mathrm{H}-\mathrm{H}_{2} \mathrm{O}\right]^{-}\right)$and $m / z 93$ [13]. This compound has already been found in Pycnogenol ${ }^{\circledR}$ [13], whereas it was identified for the first time, in this work, in P. pinea L. bark.

After confirmed by authentic standard, compound 2 was assigned as protocatechuic acid (Figure 2). In fact, this phenolic compound had been previously identified in $P$. pinaster Ait. [10] and P. pinaster Ait. var. moghrebiana barks [61], as well as in commercial pine bark extracts $[13,55]$. In contrast, protocatechuic acid was identified for the first time in $P$. pinea L. bark, to the best of our knowledge.

Compound 15 was identified as quercetin, whose retention time, molecular absorption spectrum, $[\mathrm{M}-\mathrm{H}]^{-}$at $m / z 301$, and $\mathrm{MS}^{2}$ spectrum were concordant with those of the authentic standard. This flavonol has been found in a commercial concentrated extract [56] and hydroethanolic extracts [10,37], derived from P. pinaster Ait. bark, but it has been reported here for the first time as a P. pinea L. component.

\subsubsection{Quantitative UHPLC-UV Analysis of Pinus spp. Bark Polar Extracts}

The fifteen compounds detected in the Pinus spp. bark extracts were quantified by HPLC-UV, and the individual contents of each component in the P. pinaster Ait. and P. pinea L. polar extracts are depicted in Table 4.

The total content of identified compounds varied between $14.81 \mathrm{~g} \mathrm{~kg}^{-1}$ of dry bark of $P$. pinaster Ait. and $18.56 \mathrm{~g} \mathrm{~kg}^{-1}$ of dry bark of $P$. pinea L. Quinic acid (1) represented the major compound identified in both Pinus spp. barks, accounting for $40 \%$ and $42 \%$ $(w / w)$ of the total content of the identified compounds in the P. pinaster Ait. and P. pinea L. barks, respectively. 
Table 4. Abundance of compounds identified in the Pinus pinaster Ait. and Pinus pinea L. bark polar extracts.

\begin{tabular}{|c|c|c|c|c|c|c|}
\hline \multirow{2}{*}{ No. } & \multirow{2}{*}{ Compound } & \multirow{2}{*}{$\lambda(\mathrm{nm})$} & \multicolumn{2}{|c|}{$\mathrm{g} \mathrm{kg}^{-1}$ of dw } & \multicolumn{2}{|c|}{$\mathrm{mg} \mathrm{g}^{-1}$ of Extract } \\
\hline & & & Pinus pinaster Ait. & Pinus pinea $\mathrm{L}$. & Pinus pinaster Ait. & Pinus pinea $\mathrm{L}$. \\
\hline 1 & Quinic acid ${ }^{A}$ & 280 & $5.97 \pm 0.32$ & $7.86 \pm 0.25$ & $27.98 \pm 1.12$ & $43.17 \pm 4.13$ \\
\hline \multirow[t]{2}{*}{2} & Protocatechuic acid ${ }^{B}$ & 280 & $0.35 \pm 0.01$ & $0.39 \pm 0.06$ & $1.66 \pm 0.10$ & $2.13 \pm 0.29$ \\
\hline & $\sum$ Phenolic acids & & $0.35 \pm 0.01$ & $0.39 \pm 0.06$ & $1.66 \pm 0.10$ & $2.13 \pm 0.29$ \\
\hline 3 & B-type (epi)catechin trimer isomer $1^{\mathrm{C}}$ & 280 & $<\mathrm{LOQ}^{\mathrm{F}}$ & $<\mathrm{LOQ}^{\mathrm{F}}$ & $<\mathrm{LOQ}^{\mathrm{F}}$ & $<\mathrm{LOQ}^{\mathrm{F}}$ \\
\hline 4 & B-type (epi)catechin dimer isomer $1^{\mathrm{C}}$ & 280 & $0.37 \pm 0.03$ & $0.53 \pm 0.02$ & $1.75 \pm 0.20$ & $2.89 \pm 0.24$ \\
\hline 5 & B-type (epi)catechin dimer isomer $2^{C}$ & 280 & $1.43 \pm 0.13$ & $1.63 \pm 0.09$ & $6.71 \pm 0.82$ & $8.91 \pm 0.46$ \\
\hline 6 & Catechin ${ }^{\mathrm{C}}$ & 280 & $2.29 \pm 0.30^{G(6+7)}$ & $2.80 \pm 0.17^{\mathrm{G}(6+7)}$ & $10.78 \pm 1.72 \mathrm{G}(6+7)$ & $15.30 \pm 0.84 \mathrm{G}(6+7)$ \\
\hline 7 & B-type (epi)catechin dimer isomer $3^{C}$ & 280 & $\mathrm{G}^{(6+7)}$ & $\mathrm{G}^{(6+7)}$ & $\mathrm{G}^{(6+7)}$ & $\mathrm{G}^{(6+7)}$ \\
\hline 8 & B-type (epi)catechin trimer isomer $2^{\mathrm{C}}$ & 280 & $0.78 \pm 0.09$ & $0.60 \pm 0.02$ & $3.66 \pm 0.41$ & $3.30 \pm 0.34$ \\
\hline 9 & A-type (epi)gallocatechin-(epi)catechin dimer $\mathrm{C}$ & 280 & $0.90 \pm 0.05$ & $1.16 \pm 0.10$ & $4.20 \pm 0.09$ & $6.36 \pm 0.63$ \\
\hline 10 & B-type (epi)catechin trimer isomer $3^{\mathrm{C}}$ & 280 & $0.85 \pm 0.04$ & $1.26 \pm 0.06$ & $3.99 \pm 0.30$ & $6.90 \pm 0.61$ \\
\hline 11 & B-type (epi)catechin trimer isomer $4^{\mathrm{C}}$ & 280 & $0.24 \pm 0.03$ & $0.79 \pm 0.07$ & $1.12 \pm 0.16$ & $4.29 \pm 0.10$ \\
\hline \multirow[t]{2}{*}{12} & B-type (epi)catechin dimer isomer $4^{\mathrm{C}}$ & 280 & $0.17 \pm 0.01$ & $0.13 \pm 0.01$ & $0.82 \pm 0.07$ & $0.69 \pm 0.01$ \\
\hline & E Flavan-3-ols & & $7.03 \pm 0.52$ & $8.89 \pm 0.33$ & $33.03 \pm 3.34$ & $48.66 \pm 2.46$ \\
\hline 13 & Taxifolin-O-hexoside ${ }^{\mathrm{D}}$ & 280 & $<\mathrm{LOQ}^{\mathrm{F}}$ & $0.03 \pm 0.00$ & $<\mathrm{LOQ}^{\mathrm{F}}$ & $0.18 \pm 0.01$ \\
\hline 14 & Taxifolin D & 280 & $1.46 \pm 0.00$ & $1.40 \pm 0.03$ & $6.83 \pm 0.24$ & $7.66 \pm 0.57$ \\
\hline \multirow{2}{*}{15} & $\sum$ Flavonols & & $<\mathrm{LOQ}{ }^{\mathrm{F}}$ & $<\mathrm{LOQ}^{\mathrm{F}}$ & $<\mathrm{LOQ}^{\mathrm{F}}$ & $<\mathrm{LOQ}^{\mathrm{F}}$ \\
\hline & TOTAL & & $14.81 \pm 0.20$ & $18.56 \pm 0.34$ & $69.49 \pm 3.18$ & $101.79 \pm 6.95$ \\
\hline
\end{tabular}

The values represent the mean \pm standard deviation obtained from Pinus spp. bark extracts injected in triplicate. Standard curves used for the quantification of the identified compounds: A gallic acid; ${ }^{B}$ protocatechuic acid; ${ }^{C}$ catechin; ${ }^{D}$ naringenin; ${ }^{E}$ quercetin. ${ }^{F}$ The abundance is lower than the limit of quantification (LOQ). ${ }^{\mathrm{G}}$ The abundance of compounds 6 and 7 was determined at $280 \mathrm{~nm}$, using the standard curve of catechin. 
Flavan-3-ols constituted the major phenolic subclass detected in the studied pine bark polar extracts (Table 4 ), accounting for $47 \%$ and $48 \%(w / w)$ of the total identified content in the P. pinaster Ait. and P. pinea L. barks, respectively. Considering the abundance of flavan3-ols expressed as $\mathrm{mg}$ of compound per $\mathrm{g}$ of extract, it was higher in the P. pinea L. bark extract $\left(48.66 \mathrm{mg} \mathrm{g}^{-1}\right.$ of extract) than in the $P$. pinaster Ait. Bark extract $\left(33.03 \mathrm{mg} \mathrm{g}^{-1}\right.$ of extract) (Table 4). Indeed, the flavan-3-ols contents of the Pinus spp. bark extracts analysed in the present work are concordant with that detected in Pycnogenol ${ }^{\circledR}$ [13] but lower than that reported by Romani and colleagues [55] in a commercial pine bark extract (776.6 $\mathrm{mg} \mathrm{g}^{-1}$ powder).

Moreover, catechin (6) and a B-type procyanidin dimer (7) were the main flava-3-ols present in both pine bark samples, representing $15 \%(w / w)$ of the total content of the identified compounds (Table 4). In particular, catechin and B-type procyanidin dimers accounted for $27.79 \mathrm{mg} \mathrm{g}^{-1}$ of the P. pinea L. extract and $20.06 \mathrm{mg} \mathrm{g}^{-1}$ of the P. pinaster Ait. extract, being slightly higher than that earlier evidenced for Pycnogenol ${ }^{\circledR}\left(15.49 \mathrm{mg} \mathrm{g}^{-1}\right.$ of extract) [13]. Catechin (6) has also been detected in P. pinea L. bark extracts, namely in an ethyl acetate fraction of HWE (35.8 $\mathrm{mg} \mathrm{g}^{-1}$ of extract) [17]. B-type procyanidin trimers $(8,10$, and 11) were also abundant in both pine barks, accounting for $14.2 \%(w / w)$ and $12.6 \%(w / w)$ of the total identified content in the $P$. pinea L. and P. pinaster Ait. barks, respectively. Their abundances agreed with those described for a commercial extract of P. maritima L. bark (21.1\% (w/w) of total content) [55]. To the best of our knowledge, the abundances of procyanidins in $P$. pinea L. bark are exhibited, for the first time, in this study.

Flavanonols were also detected at considerable abundances in both pine barks, representing $9.8 \%(w / w)$ and $7.7 \%(w / w)$ of the total identified contents of the P. pinaster Ait. and P. pinea L. barks, respectively (Table 4). Taxifolin (14) was the major flavanonol, accounting for $7.66 \mathrm{mg} \mathrm{g}^{-1}$ of the $P$. pinea L. bark extract and $6.83 \mathrm{mg} \mathrm{g}^{-1}$ of the P. pinaster Ait. bark extract (Table 4). Taxifolin abundance in the P. pinaster Ait. bark extract is within the range reported for commercial $P$. pinaster Ait. bark extracts $\left(1.20 \mathrm{mg} \mathrm{g}^{-1}\right.$ extract-33.1 $\mathrm{mg} \mathrm{g}^{-1}$ powder) $[13,55]$. However, the taxifolin abundance in the P. pinea L. bark polar extract was 4.2-fold lower than that reported for the ethyl fraction of HWE (28.7 $\mathrm{mg} \mathrm{g}^{-1}$ fraction) [17]. It is noteworthy that both pine barks contained much higher taxifolin abundances than the respective Spanish species (up to 12.5-fold) [18]. Regarding the taxifolin-O-hexoside (13) content, the P. pinea L. bark demonstrated a much lower content than that of Pycnogenol ${ }^{\circledR}$ (16.5-fold) [13].

Protocatechuic acid (2) was found in the P. pinaster Ait. and P. pinea L. barks, representing $2.4 \%(w / w)$ and $2.1 \%(w / w)$ of the respective biomasses (Table 4$)$. Considering its concentration, expressed as mg per $\mathrm{g}$ of extract, the studied polar extracts evidenced similar values to the published data for the commercial pine bark extracts $\left(1.81 \mathrm{mg} \mathrm{g}^{-1}\right.$ of Pycnogenol $^{\circledR}-9.1 \mathrm{mg} \mathrm{g}^{-1}$ of P. maritima L. bark extract). Furthermore, the flavonol quercetin (15) was detected in both pine bark polar extracts, however in contents lower than the limit of quantification (LOQ) of the respective standard curve (Table 4).

Taking into account the antioxidant and antibacterial activities attributed to the quinic acid and phenolic compounds identified in the P. pinaster Ait. and P. pinea L. bark [62-65], the polar extracts were herein tested regarding their antioxidant activity, via reducing power, DPPH, and ABTS scavenging effects, as well as their antibacterial activities against E. coli and S. aureus.

\subsection{Antioxidant Activity}

P. pinaster Ait. and P. pinea L. bark polar extracts were evaluated regarding their antioxidant activities by three different methods, namely reducing power, DPPH and ABTS scavenging assays. Table 5 highlights the $\mathrm{IC}_{50}$ values obtained for each extract. 
Table 5. Antioxidant activity of Pinus pinaster Ait. and Pinus pinea L. bark polar extracts, through reducing power, DPPH, and ABTS scavenging effects.

\begin{tabular}{|c|c|c|c|c|c|}
\hline \multirow[b]{2}{*}{ Extract/Standard } & \multirow{2}{*}{$\begin{array}{l}\text { Reducing Power } \\
\mathrm{IC}_{50}\left(\mu \mathrm{g} \mathrm{mL}^{-1}\right)\end{array}$} & \multicolumn{2}{|c|}{ DPPH Scavenging Effect } & \multicolumn{2}{|c|}{ ABTS Scavenging Effect } \\
\hline & & $\mathrm{IC}_{50}\left(\mu \mathrm{g} \mathrm{mL}^{-1}\right)$ & $\begin{array}{c}\mathrm{IC}_{50} \text { (mg AAE g-1 } \\
\text { of Dry Bark) }\end{array}$ & $\mathrm{IC}_{50}\left(\mu \mathrm{g} \mathrm{mL}^{-1}\right)$ & $\begin{array}{c}\mathrm{IC}_{50}\left(\mathrm{mg} \text { TE } \mathrm{g}^{-1}\right. \\
\text { of Dry Bark) }\end{array}$ \\
\hline $\begin{array}{l}\text { Pinus pinaster Ait. } \\
\text { bark polar extract }\end{array}$ & $22.53 \pm 0.46 b$ & $6.79 \pm 0.48 b$ & $125.48 \pm 12.66$ & $3.95 \pm 0.05 \mathrm{a}$ & $255.24 \pm 10.24$ \\
\hline $\begin{array}{l}\text { Pinus pinea } \text { L. bark } \\
\text { polar extract }\end{array}$ & $21.21 \pm 1.04 b$ & $6.46 \pm 0.36 b$ & $112.68 \pm 9.04$ & $3.89 \pm 0.40 \mathrm{a}$ & $223.69 \pm 10.35$ \\
\hline Ascorbic acid & - & $3.96 \pm 0.18 \mathrm{a}$ & - & $3.55 \pm 0.03 \mathrm{a}$ & - \\
\hline Trolox & $28.82 \pm 0.60 \mathrm{a}$ & - & - & $4.73 \pm 0.07 b$ & - \\
\hline
\end{tabular}

The values represent the mean \pm standard deviation. Means with different minor case letters $(a, b)$ within the same column are significantly different (one-way ANOVA, followed by Tukey's HSD test, $p<0.05$ ). Abbreviations: $\mathrm{AAE}$, Ascorbic acid equivalents; $\mathrm{IC}_{50}$, inhibitory concentration at $50 \%$. TE, Trolox equivalents.

To the best of our current knowledge, the reducing power of the P. pinaster Ait. and P. pinea L. bark polar extracts was determined for the first time in the present study. The $\mathrm{IC}_{50}$ of these extracts ranged between $21.21 \mu \mathrm{g} \mathrm{mL}{ }^{-1}$ of P. pinea L. extract and $22.53 \mu \mathrm{g} \mathrm{mL}^{-1}$ of $P$. pinaster Ait. extract. Both pine bark polar extracts were slightly more efficient than the trolox (up to 1.4-fold) $(p<0.05)$. Although the Ferric Reducing Antioxidant Power (FRAP) of phenolic-containing extracts, derived from the P. pinaster Ait. bark, was previously addressed, the mechanisms underlying this assay differ from the reducing power approach used here. To the best of our current knowledge, only pine bark extracts from P. brutia $(80 \%(v / v)$ methanol extracts) were assessed through the reducing power, evidencing a $\mathrm{IC}_{50}$ range of $9.17-11.38 \mu \mathrm{g} \mathrm{mL} \mathrm{g}^{-1}$ [43]. Thereby, both the P. pinaster Ait. and the P. pinea L. bark polar extracts were slightly less effective as reducing agents than those of the aforementioned Pinus species (2.3-fold).

The P. pinea L. and P. pinaster Ait. bark polar extracts demonstrated strong DPPH scavenging effects (Table 5), whose $\mathrm{IC}_{50}$ values were, respectively, 6.46 and $6.79 \mu \mathrm{g} \mathrm{mL}^{-1}$, which are slightly lower than that of ascorbic acid $\left(3.96 \mu \mathrm{g} \mathrm{mL}^{-1}\right)$. Considering the Antioxidant Activity Index (AAI), both pine bark polar extracts have shown much higher values (9.58 and 9.11 for the P. pinea L. and P. pinaster Ait. bark extracts, respectively) than those of the P. pinaster Ait. bark aqueous $(\mathrm{AAI}=0.53)$ and hydroethanolic $(30-90 \%(v / v)$ ethanol) extracts (0.53-1.06 AAI range). Actually, the AAI of the analysed P. pinea L. bark polar extract corresponds to up to 18.1-fold compared to the aqueous and $90 \%(v / v)$ ethanol extracts of another Portuguese P. pinaster Ait. bark [10].

Moreover, the pine extracts tested herein have shown to be more active in scavenging the DPPH free radicals than the P. pinaster Ait. bark aqueous, $50 \%(v / v)$ ethanol, and ethanol extracts (82.24-108.74 $\mathrm{mg} \mathrm{AAE} \mathrm{g}^{-1}$ dry bark), achieving up to 1.5-fold [37]. Even considering the bark extracts of other pine species, the P. pinaster Ait. and P. pinea L. bark polar extracts characterised in the present work have shown better DPPH scavenging action than the extracts obtained by Soxhlet acetone/water $(7: 3, v / v)$ and microwave-assisted extraction of $P$. radiata bark, with AAI ranges of 1.71-1.81 and 2.27-3.37, respectively [66].

The ABTS scavenging effect of $P$. pinea L. bark extract was close to that of the P. pinaster Ait. bark extract (Table 6), showing promising $\mathrm{IC}_{50}$ values of 3.89 and $3.95 \mu \mathrm{g} \mathrm{mL} \mathrm{mL}^{-1}$, respectively. Compared with the antioxidant standards, both extracts were as active as ascorbic acid in scavenging ABTS ${ }^{\bullet+}$ but less active than Trolox in this assay $(p<0.05)$. Considering the $\mathrm{IC}_{50}$ values expressed as mmol Trolox equivalents (TE) per $\mathrm{g}$ of extract, the data represented here are concordant with those described in the literature for P. pinaster Ait. bark water (4.35 mmol TE g ${ }^{-1}$ of extract) [19] and alkaline extracts (4.70-5.38 mmol TE per $\mathrm{g}^{-1}$ of extract) [40], but much stronger than ethanol extracts (28.8-fold) [10]. Moreover, both the studied extracts revealed similar ABTS scavenging actions compared to those of

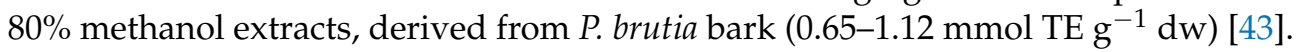


Table 6. Pearson correlation coefficients between the concentration of compounds and the $\mathrm{IC}_{50}$ values of reducing power, DPPH, and ABTS scavenging effects exhibited by Pinus pinaster Ait. and Pinus pinea L. bark polar extracts.

\begin{tabular}{|c|c|c|c|}
\hline \multirow[b]{2}{*}{ Concentration } & \multicolumn{3}{|c|}{ Pearson Correlation Coefficients $(r)$} \\
\hline & Reducing Power & $\begin{array}{c}\text { DPPH Scavenging } \\
\text { Effect }\end{array}$ & $\begin{array}{c}\text { ABTS Scavenging } \\
\text { Effect }\end{array}$ \\
\hline Total phenolic content & -0.403 & -0.146 & 0.228 \\
\hline Proanthocyanidin content & 0.289 & -0.146 & 0.625 \\
\hline Total identified compounds & -0.757 & -0.257 & -0.325 \\
\hline Total identified phenolic compounds & -0.642 & -0.203 & -0.211 \\
\hline Flavan-3-ols & -0.627 & -0.226 & -0.196 \\
\hline Flavanonols & $-0.828^{1}$ & -0.071 & -0.562 \\
\hline Quinic acid & $-0.856^{1}$ & -0.305 & -0.441 \\
\hline Protocatechuic acid & -0.363 & 0.221 & 0.226 \\
\hline B-type (epi)catechin dimer isomer 1 & -0.732 & -0.122 & -0.308 \\
\hline B-type (epi)catechin dimer isomer 2 & -0.502 & -0.098 & -0.108 \\
\hline Catechin + B-type (epi)catechin dimer isomer 3 & -0.484 & -0.119 & -0.093 \\
\hline B-type (epi)catechin trimer isomer 2 & 0.013 & -0.114 & -0.392 \\
\hline A-type (epigallocatechin-(epi)catechin dimer & -0.770 & -0.179 & -0.212 \\
\hline B-type (epi)catechin trimer isomer 3 & -0.721 & -0.416 & -0.361 \\
\hline B-type (epi)catechin trimer isomer 4 & -0.579 & -0.334 & -0.071 \\
\hline B-type (epi)catechin dimer isomer 4 & 0.721 & 0.680 & 0.217 \\
\hline Taxifolin & $-0.823^{1}$ & -0.029 & -0.605 \\
\hline
\end{tabular}

${ }^{1}$ The correlation is statistically significant at $p<0.05$.

Pearson correlations were determined between the total phenolic content, the total proanthocyanidins, and the abundances of identified compounds present in the studied pine bark polar extracts and the $\mathrm{IC}_{50}$ values of the three antioxidant activity tests, as indicated in Table 6.

The highest Pearson correlation coefficient was observed between the quinic acid content and the $\mathrm{IC}_{50}$ of the pine bark polar extracts in the reducing power assay $(r=-0.856)$. There is an increasing attention on the antioxidant activity of cyclic polyols, as quinic acid, in addition to other health-promoting effects, such as the treatment of diabetic diseases [62], paving the way for plentiful applications for this compound. Strong correlations have been also found between the flavanonols and taxifolin contents and the $\mathrm{IC}_{50}$ values of the reducing power ( $r$ values of -0.828 and -0.823 , respectively). Although the remaining linear correlations presented in Table $6 \mathrm{did}$ not have statistical significance $(p>0.05)$, the linear correlations between the taxifolin and flavanonols contents and the $\mathrm{IC}_{50}$ of extracts in the ABTS scavenging effect assay ( $r$ values of -0.605 and -0.562 , respectively), as well as the one between the C-type procyanidin trimer isomer 3 abundance and the $\mathrm{IC}_{50}$ in the DPPH scavenging assay $(r=-0.416)$, were moderate. Nevertheless, it is important to underline that other non-identified components in the analysed pine bark polar extracts may have interacted with the phenolic compounds.

\subsection{Antibacterial Activity}

The antibacterial activity of the $P$. pinaster Ait. and $P$. pinea L. bark polar extracts was assessed against two infectious agents of public health relevance, namely the Gram-positive S. aureus (ATCC ${ }^{\circledR}$ 6538) and the Gram-negative E. coli (ATCC ${ }^{\circledR}$ 25922), as illustrated in Figure 2.

The P. pinaster Ait. bark polar extracts exhibited bactericidal action in comparison with the solvent control, at a $6.25-25 \mathrm{mg} \mathrm{mL}^{-1}$ range (Figure $2 \mathrm{~A}$ ), causing 8.3-, 6.3-, and 4.0-log (CFU mL ${ }^{-1}$ ) statistically significant decreases at $6.25,12.5$, and $25 \mathrm{mg} \mathrm{mL}^{-1}$, respectively $(p<0.05)$ against the Gram-positive bacterium $S$. aureus. Furthermore, the $P$. pinea L. bark polar extracts showed a bactericidal effect at the same concentration range (Figure 2A),

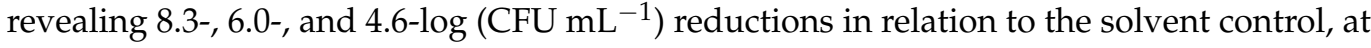


$6.25,12.5$, and $25 \mathrm{mg} \mathrm{mL}^{-1}$, respectively $(p<0.05)$. On the one hand, P. pinea L. bark polar extracts even significantly suppressed $S$. aureus growth at $3.13 \mathrm{mg} \mathrm{mL}^{-1}$ compared to the solvent control $(p<0.05)$, via bactericidal action, resulting in a 3.15-log (CFU mL $\left.{ }^{-1}\right) \operatorname{loss}$; on the other hand, P. pinaster Ait. bark polar extracts decreased $S$. aureus growth, at that concentration, with no statistical difference in comparison to the solvent control $(p>0.05)$, leading to a $2.10-\log \left(\mathrm{CFU} \mathrm{mL} \mathrm{m}^{-1}\right)$ decrease.

Regarding the inhibitory effects of Pinus spp. bark polar extracts against the Gramnegative bacterium $E$. coli growth (Figure 2B), with the $24 \mathrm{~h}$ incubation with $12.5 \mathrm{mg} \mathrm{mL}^{-1}$, no statistical difference $(p>0.05)$ was observed between the extract and the solvent control. Surprisingly, when tested at $25 \mathrm{mg} \mathrm{mL}^{-1}$, both extracts acted as strong bactericidal agents, with a significant $8.26-\log \left(\mathrm{CFU} \mathrm{mL} \mathrm{mL}^{-1}\right)$ loss in relation to the solvent control $(p<0.05)$. The essay was repeated several times, corroborating the results reported here. In fact, a previous study has already pointed out that Gram-positive bacteria are more easily inactivated by pine extracts than Gram-negative ones [67]. To the best of our knowledge, the inhibitory effect of $P$. pinea L. bark polar extract against $E$. coli is revealed here for the first time.

Some studies have highlighted the antibacterial action of $P$. pinaster Ait. and P. pinea L. bark phenolic-rich extracts against S. aureus and E. coli. Recently, Ferreira-Santos et al. [10] have demonstrated the inhibitory action of $50 \mathrm{mg} \mathrm{mL}^{-1}$ aqueous and ethanolic extracts derived from $P$. pinaster Ait. bark against S. aureus (ATCC ${ }^{\circledR}$ 6538), under the 24 h treatment, but they have not prevented E. coli (ATCC ${ }^{\circledR}$ 9337) growth, whilst Douglas et al. [13] have also proved the suppressing capacity of Pycnogenol ${ }^{\circledR}$ against methicillin-resistant S. aureus viability. Conversely, Torras et al. [20] evidenced bacteriostatic activity of $20 \mu \mathrm{g} \mathrm{mL}^{-1}$ Pycnogenol $^{\circledR}$ for S. aureus (ATCC ${ }^{\circledR}$ 6538) and E. coli (ATCC ${ }^{\circledR}$ 9337) but not bactericidal effect. All these research groups have suggested that phenolic compounds may be involved in the antibacterial action of pine bark polar extracts, with particular attention to catechin and proanthocyanidins $[68,69]$. Additionally, the hypothesis of complexation between phenolic compounds and bacterial proteins, through hydrogen bond and hydrophobic connections [20] and/or synergic effects between phenolic compounds and other extract components, should be posed. Furthermore, quinic acid present in the studied pine bark polar extracts may also have an important role in their antibacterial effect; Bai et al. [70] have recently demonstrated the antibacterial effect of quinic acid against ten foodborne pathogens, including S. aureus ATCC 6538 (minimum inhibitory concentration of $2.5 \mathrm{mg} \mathrm{mL}^{-1}$ ), with an ability to damage the normal function of the $S$. aureus cell membrane. This compound has also shown an inhibitory effect against E. coli ATCC ${ }^{\circledR} 11229$ growth (minimum inhibitory concentration of $5 \mathrm{mg} \mathrm{mL}^{-1}$ ) [70].

Considering the promising data revealed in the present study, polar fractions from Portuguese $P$. pinaster and $P$. pinea barks exhibit interesting antioxidant and antibacterial actions, which may be ascribed to quinic acid and phenolic compounds. Therefore, these forest by-products can be regarded as renewable raw materials of polar added-value bioactive compounds for food and nutraceutical and biomedical applications, such as skin care, in addition to the current energy generation, in accordance with the biorefinery concept.

\section{Conclusions}

The present study highlights promising insights on the chemical composition and related antioxidant and antibacterial activities of $P$. pinaster Ait. and $P$. pinea L. bark polar extracts. Indeed, the P. pinea L. bark polar fraction has demonstrated higher abundances of total phenolic and proanthocyanidins, as well as of quinic acid and phenolic compounds identified by UHPLC-DAD-MS ${ }^{n}$ analysis, in comparison to that of $P$. pinaster Ait. Moreover, quinic acid (1) and three phenolic compounds, namely an isomer of (epi)gallocatechin(epi)catechin dimer (9), protocatechuic acid (2), and quercetin (15), have been described herein, for the first time, as P. pinea L. bark components. Interestingly, both studied pine bark extracts have exhibited similarly effective reducing power and scavenging effects against DPPH and ABTS free radicals, being comparable to Trolox and ascorbic acid. Considering the current emergence in searching for alternative antibacterial agents, P. pinaster Ait. and 
P. pinea L. bark polar extracts have revealed bactericidal effects, at the $3.13-25 \mathrm{mg} \mathrm{mL}^{-1}$ concentration range and at $25 \mathrm{mg} \mathrm{mL}^{-1}$, against $S$. aureus and $E$. coli growth, respectively. Synergisms between quinic acid and the phenolic compounds, or even with the components of the other extracts, may have promoted the bioactivities of the pine bark polar extracts. Although there are several commercial P. pinaster Ait. bark extracts with nutraceutical usage, this knowledge can provide prospective innovative food and cosmetic applications for the studied agroforest by-products, especially with regard to the P. pinea L. bark. Nevertheless, the use of alternative solvents, such as natural deep eutectic solvents, for the extraction of quinic acid and phenolic compounds from P. pinaster Ait. and P. pinea L. barks is a further important step forward for their sustainable exploitation.

Supplementary Materials: The following are available online at https:/ /www.mdpi.com/article/ 10.3390/app12020784/s1, Figure S1: mass fragmentation of (epi)gallocatechin-( $2 \rightarrow \mathrm{O} 7,4 \rightarrow 8)$-(epi) catechin in the negative ionisation mode, Table S1: S. aureus counts after application of Pinus pinaster Ait. and Pinus pinea L. bark polar extracts, Table S2: E. coli counts after application of Pinus pinaster Ait. and Pinus pinea L. bark polar extracts.

Author Contributions: Conceptualization, P.A.B.R., S.A.O.S. and A.J.D.S.; methodology and formal analysis, P.A.B.R., C.P., A.P.G. and R.T.N.; investigation, P.A.B.R., C.P., A.P.G. and R.T.N.; writingoriginal draft preparation, P.A.B.R.; supervision, S.A.O.S., A.M.S.S., A.A. and A.J.D.S. All authors have read and agreed to the published version of the manuscript.

Funding: This work was developed within the scope of the projects CICECO-Aveiro Institute of Materials (UIDB/50011/2020 and UIDP/50011/2020), LAQV-REQUIMTE (UIDB/50006/2020 and UIDP/50006/2020), and CESAM (UIDP/50017/2020+UIDB/50017/2020+ LA/P/0094/2020), financed by national funds through the FCT/MCTES; co-financing, when adequate, by FEDER under the PT2020 Partnership Agreement. P.A.B.R., A.P.G., and S.A.O.S. acknowledge the "AgroForWealth" project (CENTRO-01-0145-FEDER-000001) funded by Centro2020, through FEDER and PT2020 for the post-doctoral grant of P.A.B.R. and A.P.G. and S.A.O.S. contracts. C.P. was supported by a junior research contract (CEEC individual/03974/2017) financed by FCT.

Conflicts of Interest: The authors declare no conflict of interest.

\section{References}

1. UN. Transforming Our World: The 2030 Agenda for Sustainable Development. Available online: https://sdgs.un.org/2030agenda (accessed on 30 June 2021).

2. FAO; UNEP. The State of the World's Forests 2020—Forests, Biodiversity and People. Available online: https://doi.org/10.4060/ ca8642en (accessed on 30 June 2021).

3. ICNF. IFN $6-6^{\circ}$ Inventário Florestal Nacional. Available online: https:/ /www.agroportal.pt/6o-inventario-florestal-nacional/ (accessed on 30 June 2021).

4. Viñas, R.A.; Caudullo, G.; Oliveira, S.; de Rigo, D. Pinus pinea in Europe: Distribution, habitat, usage and threats. In European Atlas of Forest Tree Species; San-Miguel-Ayanz, J., de Rigo, D., Caudullo, G., Houston Durrant, T., Mauri, A., Eds.; Publications Office of the European Union: Luxembourg, 2016; p. 130.

5. Centro PINUS. A Fileira Do Pinho Em 2019-Indicadores Da Fileira Do Pinho. Available online: https://www.centropinus.org/ files/upload/indicadores/indicadores-centro-pinus-2020-1.pdf (accessed on 30 June 2021).

6. Nergiz, C.; Dönmez, İ. Chemical Composition and Nutritive Value of Pinus pinea L. Seeds. Food Chem. 2004, 86, 365-368. [CrossRef]

7. Mármol, I.; Quero, J.; Jiménez-Moreno, N.; Rodríguez-Yoldi, M.J.; Ancín-Azpilicueta, C. A Systematic Review of the Potential Uses of Pine Bark in Food Industry and Health Care. Trends Food Sci. Technol. 2019, 88, 558-566. [CrossRef]

8. Rohdewald, P. A Review of the French Maritime Pine Bark Extract (Pycnogenol), a Herbal Medication with a Diverse Clinical Pharmacology. Int. J. Clin. Pharmacol. Ther. 2002, 40, 158-168. [CrossRef]

9. Ferreira-Santos, P.; Zanuso, E.; Genisheva, Z.; Rocha, C.M.R.; Teixeira, J.A. Green and Sustainable Valorization of Bioactive Phenolic Compounds from Pinus By-Products. Molecules 2020, 25, 2931. [CrossRef]

10. Ferreira-Santos, P.; Genisheva, Z.; Botelho, C.; Santos, J.; Ramos, C.; Teixeira, J.A.; Rocha, C.M.R. Unravelling the Biological Potential of Pinus pinaster Bark Extracts. Antioxidants 2020, 9, 334. [CrossRef]

11. Venditti, A.; Maggi, F.; Saab, A.M.; Bramucci, M.; Quassinti, L.; Petrelli, D.; Vitali, L.A.; Lupidi, G.; el Samrani, A.; Borgatti, M.; et al. Antiproliferative, Antimicrobial and Antioxidant Properties of Cedrus Libani and Pinus pinea Wood Oils and Juniperus Excelsa Berry Oil. Plant Biosyst. 2020, 1-12. [CrossRef] 
12. Fekih, N.; Allali, H.; Merghache, S.; Bouchentouf, S.; Costa, J. In Vitro Assessment of Two Species of the Genus Pinus Growing in Algeria for Their Antimicrobial and Antioxidant Activity. Agric. Conspec. Sci. 2019, 84, 103-114.

13. Douglas, T.E.L.; Lopez-Heredia, M.A.; Pulczynska, A.; Łapa, A.; Pietryga, K.; Schaubroeck, D.; Santos, S.; Pais, A.; Brackman, G.; de Schamphelaere, K.; et al. Phenolic Plant Extract Enrichment of Enzymatically Mineralized Hydrogels. Eng. Biomater. 2019, 149, 2-9.

14. Hameş-Kocabaş, E.E.; Yeşil-Çeliktaş, Ö.; İşleten, M.; Vardar-Sukan, F. Antimicrobial Activity of Pine Bark Extract and Assessment of Potential Application in Cooked Red Meat. Gida 2008, 33, 123-127.

15. Moreirinha, C.; Vilela, C.; Silva, N.H.C.S.; Pinto, R.J.B.; Almeida, A.; Rocha, M.A.M.; Coelho, E.; Coimbra, M.A.; Silvestre, A.J.D.; Freire, C.S.R. Antioxidant and Antimicrobial Films Based on Brewers Spent Grain Arabinoxylans, Nanocellulose and Feruloylated Compounds for Active Packaging. Food Hydrocoll. 2020, 108, 105836. [CrossRef]

16. Morais, E.S.; Silva, N.H.C.S.; Sintra, T.E.; Santos, S.A.O.; Neves, B.M.; Almeida, I.F.; Costa, P.C.; Correia-Sá, I.; Ventura, S.P.M.; Silvestre, A.J.D.; et al. Anti-Inflammatory and Antioxidant Nanostructured Cellulose Membranes Loaded with Phenolic-Based Ionic Liquids for Cutaneous Application. Carbohydr. Polym. 2019, 206, 187-197. [CrossRef]

17. Yesil-Celiktas, O.; Ganzera, M.; Akgun, I.; Sevimli, C.; Korkmaz, K.S.; Bedir, E. Determination of Polyphenolic Constituents and Biological Activities of Bark Extracts from Different Pinus Species. J. Sci. Food Agric. 2009, 89, 1339-1345. [CrossRef]

18. Gascón, S.; Jiménez-Moreno, N.; Jiménez, S.; Quero, J.; Rodríguez-Yoldi, M.J.; Ancín-Azpilicueta, C. Nutraceutical Composition of Three Pine Bark Extracts and Their Antiproliferative Effect on Caco-2 Cells. J. Funct. 2018, 48, 420-429. [CrossRef]

19. Touriño, S.; Selga, A.; Jiménez, A.; Juliá, L.; Lozano, C.; Lizárraga, D.; Cascante, M.; Torres, J.L. Procyanidin Fractions from Pine (Pinus pinaster) Bark: Radical Scavenging Power in Solution, Antioxidant Activity in Emulsion, and Antiproliferative Effect in Melanoma Cells. J. Agric. Food Chem. 2005, 53, 4728-4735. [CrossRef] [PubMed]

20. Torras, M.A.C.; Faura, C.A.; Schönlau, F.; Rohdewald, P. Antimicrobial Activity of Pycnogenol ${ }^{\circledR}$. Phytother. Res. 2005, 19, 647-648. [CrossRef]

21. Ramos, P.A.B.; Moreirinha, C.; Silva, S.; Costa, E.M.; Veiga, M.; Coscueta, E.; Santos, S.A.O.; Almeida, A.; Pintado, M.M.; Freire, C.S.R.; et al. The Health-Promoting Potential of Salix spp. Bark Polar Extracts: Key Insights on Phenolic Composition and in Vitro Bioactivity and Biocompatibility. Antioxidants 2019, 8, 609. [CrossRef]

22. Sousa, J.L.C.; Ramos, P.A.B.; Freire, C.S.R.; Silva, A.M.S.; Silvestre, A.J.D. Chemical Composition of Lipophilic Bark Extracts from Pinus pinaster and Pinus pinea Cultivated in Portugal. Appl. Sci. 2018, 8, 2575. [CrossRef]

23. Santos, S.A.O.; Vilela, C.; Domingues, R.M.A.; Oliveira, C.S.D.; Villaverde, J.J.; Freire, C.S.R.; Neto, C.P.; Silvestre, A.J.D. Secondary Metabolites from Eucalyptus Grandis Wood Cultivated in Portugal, Brazil and South Africa. Ind. Crops Prod. 2017, 95, 357-364. [CrossRef]

24. Vogel, M.; Schmitz, R.P.H.; Hagel, S.; Pletz, M.W.; Gagelmann, N.; Scherag, A.; Schlattmann, P.; Brunkhorst, F.M. Infections Disease Consultation for Staphylococcus aureus Bacteremia-A Systematic Review and Meta-Analysis. J. Infect. 2016, 72, 19-28. [CrossRef]

25. Vila, J.; Sáez-López, E.; Johnson, J.R.; Römling, U.; Dobrindt, U.; Cantón, R.; Giske, C.G.; Naas, T.; Carattoli, A.; Martínez-Medina, M.; et al. Escherichia coli: An Old Friend with New Tidings. FEMS Microbiol. Rev. 2016, 40, 437-463. [CrossRef]

26. Singleton, V.L.; Rossi, J.A. Colorimetry of Total Phenolics with Phosphomolybdic-Phosphotungstic Acid Reagents. Am. J. Enol. Vitic. 1965, 16, 144-158.

27. Neto, R.T.; Santos, S.A.O.; Oliveira, J.; Silvestre, A.J.D. Tuning of Proanthocyanidin Extract's Composition through Quaternary Eutectic Solvents Extraction. Antioxidants 2020, 9, 1124. [CrossRef]

28. Oyaizu, M. Studies on Products of Browning Reaction. Jpn. J. Nutr. Diet. 1986, 44, 307-315. [CrossRef]

29. Berker, K.I.; Güçlü, K.; Tor, İ.; Apak, R. Comparative Evaluation of Fe(III) Reducing Power-Based Antioxidant Capacity Assays in the Presence of Phenanthroline, Batho-Phenanthroline, Tripyridyltriazine (FRAP), and Ferricyanide Reagents. Talanta 2007, 72, 1157-1165. [CrossRef]

30. Pais, A.C.S.; Pinto, C.A.; Ramos, P.A.B.; Pinto, R.J.B.; Rosa, D.; Duarte, M.F.; Abreu, M.H.; Rocha, S.M.; Saraiva, J.A.; Silvestre, A.J.D.; et al. High pressure extraction of bioactive diterpenes from the macroalgae Bifurcaria bifurcata: An efficient and environmentally friendly approach. RSC Adv. 2019, 9, 39893-39903. [CrossRef]

31. Scherer, R.; Godoy, H.T. Antioxidant Activity Index (AAI) by the 2,2-Diphenyl-1-Picrylhydrazyl Method. Food Chem. 2009, 112, 654-658. [CrossRef]

32. Re, R.; Pellegrini, N.; Proteggente, A.; Pannala, A.; Yang, M.; Rice-Evans, C. Antioxidant Activity Applying an Improved ABTS Radical Cation Decolorization Assay. Free Radic. Biol. Med. 1999, 26, 1231-1237. [CrossRef]

33. Ramos, P.A.B.; Santos, S.A.O.; Guerra, Â.R.; Guerreiro, O.; Freire, C.S.R.; Rocha, S.M.; Duarte, M.F.; Silvestre, A.J.D. Phenolic Composition and Antioxidant Activity of Different Morphological Parts of Cynara cardunculus L. var. Altilis (DC). Ind. Crops Prod. 2014, 61, 460-471. [CrossRef]

34. Nunes, E.; Quilhó, T.; Pereira, H. Anatomy and Chemical Composition of Pinus pinaster Bark. IAWA J. 1996, 17, 141-150. [CrossRef]

35. Fradinho, D.M.; Neto, C.P.; Evtuguin, D.; Jorge, F.C.; Irle, M.A.; Gil, M.H.; de Jesus, J.P. Chemical Characterisation of Bark and of Alkaline Bark Extracts from Maritime Pine Grown in Portugal. Ind. Crops Prod. 2002, 16, 23-32. [CrossRef]

36. Nunes, E.; Quilhó, T.; Pereira, H. Anatomy and Chemical Composition of Pinus pinea L. Bark. Ann. For. Sci. 1999, 56, 479-484. [CrossRef] 
37. Vieito, C.; Pires, P.; Fernandes, É.; Velho, M. Chemical Characterization of Pine Bark (Pinus pinaster Aiton Subsp. Atlantica), Antioxidant Properties and Phenolic Profile of Its Extracts. Millenium 2019, 8, 79-87. [CrossRef]

38. Seabra, I.J.; Dias, A.M.A.; Braga, M.E.M.; de Sousa, H.C. High Pressure Solvent Extraction of Maritime Pine Bark: Study of Fractionation, Solvent Flow Rate and Solvent Composition. J. Supercrit. Fluids 2012, 62, 135-148. [CrossRef]

39. Dudonné, S.; Vitrac, X.; Coutière, P.; Woillez, M.; Mérillon, J.-M. Comparative Study of Antioxidant Properties and Total Phenolic Content of 30 Plant Extracts of Industrial Interest Using DPPH, ABTS, FRAP, SOD, and ORAC Assays. J. Agric. Food Chem. 2009, 57, 1768-1774. [CrossRef] [PubMed]

40. Galiñanes, C.; Freire, M.S.; González-Álvarez, J. Antioxidant Activity of Phenolic Extracts from Chestnut Fruit and Forest Industries Residues. Eur. J. Wood Wood Prod. 2015, 73, 651-659. [CrossRef]

41. Ustun, O.; Senol, F.S.; Kurkcuoglu, M.; Orhan, I.E.; Kartal, M.; Baser, K.H.C. Investigation on Chemical Composition, Anticholinesterase and Antioxidant Activities of Extracts and Essential Oils of Turkish Pinus Species and Pycnogenol. Ind. Crops Prod. 2012, 38, 115-123. [CrossRef]

42. Ku, C.S.; Jang, J.P.; Mun, S.P. Exploitation of Polyphenol-Rich Pine Barks for Potent Antioxidant Activity. J. Wood Sci. 2007, 53, 524-528. [CrossRef]

43. Cretu, E.; Karonen, M.; Salminen, J.-P.; Mircea, C.; Trifan, A.; Charalambous, C.; Constantinou, A.I.; Miron, A. In Vitro Study on the Antioxidant Activity of a Polyphenol-Rich Extract from Pinus Brutia Bark and Its Fractions. J. Med. Food 2013, 16, 984-991. [CrossRef]

44. Chupin, L.; Motillon, C.; Bouhtoury, F.C.-E.; Pizzi, A.; Charrier, B. Characterisation of Maritime Pine (Pinus pinaster) Bark Tannins Extracted under Different Conditions by Spectroscopic Methods, FTIR and HPLC. Ind. Crops Prod. 2013, 49, 897-903. [CrossRef]

45. Scalbert, A.; Monties, B.; Janin, G. Tannins in Wood: Comparison of Different Estimation Methods. J. Agric. Food Chem. 1989, 37, 1324-1329. [CrossRef]

46. Simões, R.; Pimentel, C.; Ferreira-Dias, S.; Miranda, I.; Pereira, H. Phytochemical characterization of phloem in maritime pine and stone pine in three sites in Portugal. Heliyon 2021, 7, e06718. [CrossRef]

47. Santos, S.A.O.; Vilela, C.; Camacho, J.F.; Cordeiro, N.; Gouveia, M.; Freire, C.S.R.; Silvestre, A.J.D. Profiling of Lipophilic and Phenolic Phytochemicals of Four Cultivars from Cherimoya (Annona cherimola Mill.). Food Chem. 2016, 211, 845-852. [CrossRef]

48. Teixeira, N.; Azevedo, J.; Mateus, N.; de Freitas, V. Proanthocyanidin Screening by LC-ESI-MS of Portuguese Red Wines Made with Teinturier Grapes. Food Chem. 2016, 190, 300-307. [CrossRef]

49. Ramos, P.A.B.; Moreirinha, C.; Santos, S.A.O.; Almeida, A.; Freire, C.S.R.; Silva, A.M.S.; Silvestre, A.J.D. Valorisation of Bark Lipophilic Fractions from Three Portuguese Salix Species: A Systematic Study of the Chemical Composition and Inhibitory Activity on Escherichia coli. Ind. Crops Prod. 2019, 132, 245-252. [CrossRef]

50. Hamed, A.I.; Al-Ayed, A.S.; Moldoch, J.; Piacente, S.; Oleszek, W.; Stochmal, A. Profiles Analysis of Proanthocyanidins in the Argun Nut (Medemia argun-An Ancient Egyptian Palm) by LC-ESI-MS/MS. J. Mass Spectrom. 2014, 49, 306-315. [CrossRef] [PubMed]

51. Svensson, L.; Sekwati-Monang, B.; Lutz, D.L.; Schieber, A.; Gänzle, M.G. Phenolic Acids and Flavonoids in Nonfermented and Fermented Red Sorghum (Sorghum bicolor (L.) Moench). J. Agric. Food Chem. 2010, 58, 9214-9220. [CrossRef] [PubMed]

52. Kang, J.; Price, W.E.; Ashton, J.; Tapsell, L.C.; Johnson, S. Identification and Characterization of Phenolic Compounds in Hydromethanolic Extracts of Sorghum Wholegrains by LC-ESI-MSn. Food Chem. 2016, 211, 215-226. [CrossRef] [PubMed]

53. Touati, R.; Santos, S.A.O.; Rocha, S.M.; Belhamel, K.; Silvestre, A.J.D. Phenolic Composition and Biological Prospecting of Grains and Stems of Retama sphaerocarpa. Ind. Crops Prod. 2017, 95, 244-255. [CrossRef]

54. Santos, S.A.O.; Vilela, C.; Freire, C.S.R.; Neto, C.P.; Silvestre, A.J.D. Ultra-High Performance Liquid Chromatography Coupled to Mass Spectrometry Applied to the Identification of Valuable Phenolic Compounds from Eucalyptus Wood. J. Chromatogr. B 2013, 938, 65-74. [CrossRef]

55. Romani, A.; Ieri, F.; Turchetti, B.; Mulinacci, N.; Vincieri, F.F.; Buzzini, P. Analysis of Condensed and Hydrolysable Tannins from Commercial Plant Extracts. J. Pharm. Biomed. 2006, 41, 415-420. [CrossRef] [PubMed]

56. de la Luz Cadiz-Gurrea, M.; Fernandez-Arroyo, S.; Segura-Carretero, A. Pine Bark and Green Tea Concentrated Extracts: Antioxidant Activity and Comprehensive Characterization of Bioactive Compounds by HPLC-ESI-QTOF-MS. Int. J. Mol. Sci. 2014, 15, 20382-20402. [CrossRef]

57. Lin, L.-Z.; Sun, J.; Chen, P.; Monagas, M.J.; Harnly, J.M. UHPLC-PDA-ESI/HRMSn Profiling Method To Identify and Quantify Oligomeric Proanthocyanidins in Plant Products. J. Agric. Food Chem. 2014, 62, 9387-9400. [CrossRef]

58. Weber, H.A.; Hodges, A.E.; Guthrie, J.R.; O’Brien, B.M.; Robaugh, D.; Clark, A.P.; Harris, R.K.; Algaier, J.W.; Smith, C.S. Comparison of Proanthocyanidins in Commercial Antioxidants: Grape Seed and Pine Bark Extracts. J. Agric. Food Chem. 2007, 55, 148-156. [CrossRef]

59. Esatbeyoglu, T.; Wray, V.; Winterhalter, P. Identification of Two Novel Prodelphinidin A-Type Dimers from Roasted Hazelnut Skins (Corylus avellana L.). J. Agric. Food Chem. 2013, 61, 12640-12645. [CrossRef]

60. Ye, M.; Yang, W.-Z.; Liu, K.-D.; Qiao, X.; Li, B.-J.; Cheng, J.; Feng, J.; Guo, D.-A.; Zhao, Y.-Y. Characterization of Flavonoids in Millettia nitida var. Hirsutissima by HPLC/DAD/ESI-MSn. J. Pharm. Anal. 2012, 2, 35-42. [CrossRef]

61. Benlarbi, R.; Fechtal, M.; Meziane, D.; Istambouli, A. Carboxylic Acids of Moroccan Pinus pinaster Bark Extract. Holzforschung 1999, 53, 580-584. [CrossRef] 
62. Karaman, M.; Tesanovic, K.; Gorjanovic, S.; Pastor, F.T.; Simonovic, M.; Glumac, M.; Pejin, B. Polarography as a Technique of Choice for the Evaluation of Total Antioxidant Activity: The Case Study of Selected Coprinus comatus Extracts and Quinic Acid, Their Antidiabetic Ingredient. Nat. Prod. Res. 2021, 35, 1711-1716. [CrossRef]

63. Jerez, M.; Touriño, S.; Sineiro, J.; Torres, J.L.; Núñez, M.J. Procyanidins from Pine Bark: Relationships between Structure, Composition and Antiradical Activity. Food Chem. 2007, 104, 518-527. [CrossRef]

64. Artem'eva, O.A.; Pereselkova, D.A.; Fomichev, Y.P. Dihydroquercetin, the Bioactive Substance, to Be Used against Pathogenic Microorganisms as an Alternative to Antibiotics. Selskokhoziaistvennaia Biol. 2015, 50, 513-519. [CrossRef]

65. Cueva, C.; Moreno-Arribas, M.V.; Martín-Álvarez, P.J.; Bills, G.; Vicente, M.F.; Basilio, A.; Rivas, C.L.; Requena, T.; Rodríguez, J.M.; Bartolomé, B. Antimicrobial Activity of Phenolic Acids against Commensal, Probiotic and Pathogenic Bacteria. Res. Microbiol. 2010, 161, 372-382. [CrossRef]

66. Aspé, E.; Fernández, K. The Effect of Different Extraction Techniques on Extraction Yield, Total Phenolic, and Anti-Radical Capacity of Extracts from Pinus radiata Bark. Ind. Crops Prod. 2011, 34, 838-844. [CrossRef]

67. Nisca, A.; Ștefănescu, R.; Stegăruș, D.I.; Mare, A.D.; Farczadi, L.; Tanase, C. Comparative study regarding the chemical composition and biological activity of Pine (Pinus nigra and P. sylvestris) bark extracts. Antioxidants 2021, 10, 327. [CrossRef]

68. Ajiboye, T.O.; Aliyu, M.; Isiaka, I.; Haliru, F.Z.; Ibitoye, O.B.; Uwazie, J.N.; Muritala, H.F.; Bello, S.A.; Yusuf, I.I.; Mohammed, A.O. Contribution of Reactive Oxygen Species to (+)-Catechin-Mediated Bacterial Lethality. Chem. Biol. Interact. 2016, 258, $276-287$. [CrossRef]

69. Mayer, R.; Stecher, G.; Wuerzner, R.; Silva, R.C.; Sultana, T.; Trojer, L.; Feuerstein, I.; Krieg, C.; Abel, G.; Popp, M.; et al. Proanthocyanidins: Target Compounds as Antibacterial Agents. J. Agric. Food Chem. 2008, 56, 6959-6966. [CrossRef]

70. Bai, J.; Wu, Y.; Wang, X.; Liu, X.; Zhong, K.; Huang, Y.; Chen, Y.; Gao, H. In Vitro and in Vivo Characterization of the Antibacterial Activity and Membrane Damage Mechanism of Quinic Acid against Staphylococcus aureus. J. Food Saf. 2018, 38, e12416. [CrossRef] 